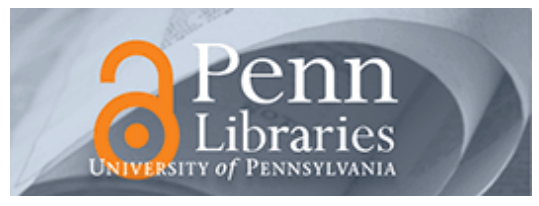

University of Pennsylvania

ScholarlyCommons

Management Papers

Wharton Faculty Research

$10-2014$

\title{
Do Analysts Add Value When They Most Can? Evidence From Corporate Spin-Offs
}

Emilie R. Feldman

University of Pennsylvania

Stuart C. Gilson

Belén Villalonga

Follow this and additional works at: https://repository.upenn.edu/mgmt_papers

Part of the Business Administration, Management, and Operations Commons, and the Strategic Management Policy Commons

\section{Recommended Citation}

Feldman, E. R., Gilson, S. C., \& Villalonga, B. (2014). Do Analysts Add Value When They Most Can?

Evidence From Corporate Spin-Offs. Strategic Management Journal, 35 (10), 1446-1463. http://dx.doi.org/ 10.1002/smj.2169

This paper is posted at ScholarlyCommons. https://repository.upenn.edu/mgmt_papers/39

For more information, please contact repository@pobox.upenn.edu. 


\title{
Do Analysts Add Value When They Most Can? Evidence From Corporate Spin- Offs
}

\begin{abstract}
This article investigates how securities analysts help investors understand the value of diversification. By studying the research that analysts produce about companies that have announced corporate spin-offs, we gain unique insights into how analysts portray diversified firms to the investment community. We find that while analysts' research about these companies is associated with improved forecast accuracy, the value of their research about the spun-off subsidiaries is more limited. For both diversified firms and their spun-off subsidiaries, analysts' research is more valuable when information asymmetry between the management of these entities and investors is higher. These findings contribute to the corporate strategy literature by shedding light on the roots of the diversification discount and by showing how analysts' research enables investors to overcome asymmetric information.
\end{abstract}

\section{Keywords}

analysts, spin-offs, diversification discount, information asymmetry, corporate strategy

Disciplines

Business Administration, Management, and Operations | Strategic Management Policy 


\title{
When Do Analysts Add Value?
}

\section{Evidence from Corporate Spinoffs}

\author{
Emilie Feldman Stuart Gilson Belén Villalonga \\ efeldman@hbs.edu sgilson@hbs.edu bvillalonga@hbs.edu
}

Harvard Business School

Soldiers Field

Boston, MA 02163

Draft, March 8, 2010

\begin{abstract}
We would like to thank Gabriel Natividad, Cynthia Montgomery, Felix Oberholzer, and seminar participants at HEC Lausanne for their comments. We thank Patrick Barton, Mercedes Boland, Qin Ding, Victor Doherty, Alexander Fisher, Michael Hauschild, Nick Hurley, Benjamin Istvan, Benjamin Kaufman, Patrick Lo, James Moran, George Saalouke, Michael Skey, Robert Steele, Jeremy Stone, Robert Tau, Huong Trieu, Lois Wang, and Jeff Wu for their assistance in collecting and coding the data from analyst reports, and Boris Groysberg for providing part of the data about analysts. We gratefully acknowledge the financial support of the Division of Research at the Harvard Business School. All errors are our own.
\end{abstract}




\title{
When Do Analysts Add Value?
}

\section{Evidence from Corporate Spinoffs}

\begin{abstract}
We investigate the information content and forecast accuracy of 1,793 analyst reports written around 62 spinoffs - a setting in which analysts' ability to inform investors is potentially very high. We find that analysts pay little attention to subsidiaries about to be spun off even though these subsidiaries constitute a significant part of the parent company operations. Moreover, while the level of detail in analyst research about parent companies is significantly related to EPS and price forecast accuracy, the same is not true for the subsidiaries. We establish that this "forgotten child" phenomenon is linked to a "neglected parent" effect, whereby inaccuracy in subsidiary earnings forecasts is associated with inaccuracy in parent estimates. We conclude by showing that spinoffs may be a particularly complex setting for analysts to evaluate relative to other forms of corporate restructuring, such as IPOs, mergers, or bankruptcies, providing one potential explanation for our findings.
\end{abstract}


The impact of financial analysts on capital market efficiency has been much debated in academia and in practice. A large body of academic research finds that analysts act as important information intermediaries, generating financial forecasts, stock recommendations and other fundamental research which helps investors form more precise estimates of stock prices, thereby contributing to the overall efficiency of capital markets (Givoly and Lakonishok, 1979; Francis and Soffer, 1997; Hong et al., 2000; Gleason and Lee, 2003; Jegadeesh et al., 2004; Kelly and Ljungqvist, 2008). Other research, however, has identified situations and contexts in which the value of analyst coverage may be relatively more limited, such as when analysts face possible conflicts of interest (Lin and McNichols, 1998; Michaely and Womack, 1999; Ljungqvist et al., 2006; Agrawal and Chen, 2008; Kolasinki and Kothari, 2008), or when the company or situation they are presented with is especially complex (Haw et al., 1994; Gilson, 2000) or not wellmatched to their area of expertise (Krishnaswami and Subramaniam, 1999; Gilson et al., 2001; Clement et al., 2007). Still other research suggests that the informativeness of analyst recommendations, and the depth of analyst coverage, may have been adversely affected by certain regulatory changes. These include the adoption, in 2000, of Regulation Fair Disclosure (FD), which limited companies' ability to selectively disclose information to analysts and investors (Gintschel and Markov, 2004; Agrawal et al., 2006; Gomes et al., 2007), and the 2003 Global Settlement between ten leading investment banks and Federal and State regulators, which enforced greater separation between the banks' research and investment banking activities (Kadan et al., 2009).

In this paper, we examine how much value analysts create as information intermediaries in a setting in which their ability to inform investors is potentially very high: corporate spinoffs. When a firm spins off a subsidiary or division, each current outstanding share is in effect 
converted into two new shares, representing separate claims on the stand-alone operations of the parent and newly-independent subsidiary. Prior to the effective date of the spinoff, therefore, actual or potential investors in the parent firm stock will benefit from any useful information that analysts can provide them about how the spinoff will impact value and the future financial performance of both the parent and the subsidiary.

The potential for analysts to add value in this situation is especially high because while the new entities created by the spinoff have no stock price history—similar to an IPO — analysts may have been following the businesses of the parent and subsidiary for an extended time, giving them a comparative advantage in forecasting both entities' future financial performance. ${ }^{1}$ Analysts' knowledge about the company and their industry expertise should also give them a comparative advantage in forecasting how shared corporate assets, liabilities, and overhead expense will be allocated between the parent and subsidiary as part of the separation of the two entities (analogous to dividing up common property in a divorce).

Humana Inc.'s spinoff of Galen Health Care provides a case in point. As the nation's largest health care provider, the company was diversified into two distinct businesses: health plan management, and hospital ownership and operation. In the early 1990's, Humana's management began to question the wisdom of this integrated strategy and eventually announced that it would be spinning off its hospital business under the Galen name. In structuring the transaction, one critical issue that emerged was how to allocate debt and corporate overhead between the two entities. An unsophisticated investor might have followed a simple rule of allocating these shared resources in proportion to each business' contribution to the integrated company's total assets, sales or profits. In fact, such rules are even used by sophisticated

\footnotetext{
${ }^{1}$ In our sample, the time elapsed between the initial spinoff announcement and the effective date of the spinoff is as long as two years.
} 
academic researchers in large sample empirical studies-e.g. Berger and Ofek (1995) and subsequent studies of the conglomerate discount-where a more detailed analysis of each company is impractical. In contrast, a better informed and more dedicated financial analyst hypothetically following Humana might realize that such a rule would have resulted in a nonsensical allocation of corporate overhead in this case, since the less asset-intensive business - health plans — was the one that made greater use of the company's shared computer and data processing systems (Gilson, 1994).

Various factors may offset the apparent advantages that analysts have in assessing the impact of a spinoff, however. Prior to the spinoff, the firm may have reported relatively limited segment data, or have been lax in allocating overhead to individual business segments. When the parent and subsidiary conduct business with one another, identifying the stand-alone profitability of each can be confounded by transfer pricing issues. Analysts typically specialize in following certain industries, so they may produce less accurate forecasts when the parent and subsidiary operate in different industries (Zuckerman, 1999; Gilson et al., 2001). ${ }^{2}$ The spinoff may be motivated by changes in the firm's industry or markets, which by themselves make it more difficult to forecast future financial performance. And, in the wake of Regulation FD and the Global Settlement, analysts may lack access to valuable information about the spinoff that they might previously have obtained from management or their firm’s investment banking division. Whether analysts are able to provide investors with useful information in a situation where such information is particularly valuable is, therefore, an empirical question.

\footnotetext{
${ }^{2}$ Zuckerman (1999) shows that conglomerates are discounted to the extent that they are not covered by the analysts who specialize in their industries. Gilson et al. (2001) further show that, when those conglomerates are broken up through spinoffs, equity carve-outs, or tracking stock offerings, there are significant forecast improvements resulting from the increased coverage (of the "pieces") by industry-specialized analysts.
} 
This paper provides empirical evidence on the quantity and quality of analysts' research for a large sample of pending equity spinoffs and tracking stock offerings. Our sample includes 62 firms that announced a spinoff or the creation of a tracking stock between 1985 and 2000. We focus on transactions that were announced before October 2000, thereby excluding the impact of Regulation FD and the Global Settlement, so that we can conduct a more powerful test of analysts' ability to produce valuable information for investors. This type of analyst research and its outcome (separate price and earnings forecasts for parent and subsidiary) can only be observed in the actual analyst reports, not in any electronic database like I/B/E/S or Zacks. Therefore, we manually collected information from 1,793 analyst reports issued for our sample firms.

An important contribution of this paper is that it is one of the first to provide very finegrained detail on the quantity and types of analyses included in analyst reports, a feature it shares with only three other papers: Gilson's (2000) clinical study of the United Airlines employee buyout, and the large-sample studies of Asquith et al. (2005) and Houston et al. (2006). The most striking result that emerges from our descriptive analysis is what we refer to as the "forgotten child” effect. Namely, in their reports about companies that have announced a spinoff, analysts provide less information about subsidiaries that are to be spun off and make much less accurate earnings forecasts for them than they do for the parent companies, even though these subsidiaries represent a significant fraction of the combined entities’ assets and sales (about 45\% and 20\%, respectively). The relative lack of attention given to subsidiaries in analysts’ published research is remarkable, since any forecast of the parent's future performance must account for the loss of the subsidiary's business, so analysts must necessarily analyze the financial performance of both the parent and the subsidiary. 
To better understand what is driving the results of our descriptive analysis, we use singleand two-stage regression models to examine the relation between the information content of analyst reports and the accuracy of their earnings and price forecasts about both the parent and subsidiary companies. We find that the accuracy of parent EPS forecasts is quite significantly related to a number of variables representing the information reported by analysts, including the number of annual earnings forecasts and the number of financial statements provided about the parent company. These EPS forecasts are also associated with several other relevant factors, such as the industrial relatedness of the parent and subsidiary firms, and the industry expertise of the analyst or the brokerage firm. In contrast to the parent company results, very few factors seem to influence the accuracy of subsidiary EPS forecasts, even after controlling for unobserved heterogeneity and for possible selection bias. Moreover, there are few factors associated with price forecast accuracy, particularly for subsidiaries, perhaps reflecting the fact that is very difficult for anyone, analysts included, to make accurate stock price forecasts.

In light of these findings, we then consider whether analysts' tendency to "forget the child," the spun-off subsidiary, in turn leads them to "neglect the parent” by making less accurate forecasts about it. We investigate this question by considering the extent to which subsidiary forecast errors are associated with parent forecast errors. We find that when analysts make lessaccurate earnings forecasts about the subsidiary, they also make less accurate forecasts about the parent company, providing support for the "forgotten child, neglected parent" hypothesis.

One potential explanation for our results is that the task of forecasting earnings and stock prices at the time of an impending spinoff may be particularly complex, perhaps even more so than it is in other "special situations" such as IPOs, mergers, bankruptcies, and other forms of 
corporate restructuring. A comparison of the accuracy of analysts' price and earnings forecasts to those reported in studies of other such special situations provides support for this explanation.

The remainder of the paper is organized as follows. Section 1 describes the data and sample for our study. Section 2 presents the results of our descriptive analysis of the quantity and type of information provided by analysts in anticipation of corporate spinoffs. Sections 3 and 4 analyze the quality of that information to the extent that it influences the accuracy of earnings and price forecasts, respectively. Section 5 compares the accuracy of analyst forecasts in our sample of spinoffs with what other studies have reported for other types of complex transactions. Section 6 concludes.

\section{Data and Sample}

Our sample consists of 1,793 analyst reports covering the parent company and/or the subsidiary from a random sample of 62 refocusing transactions (58 spinoffs and 4 tracking stock issues) which were announced between 1985 and 2000. In the remainder of the paper, we refer to all of these transactions as "spinoffs" indistinctively.

The dataset was constructed as follows. First, an initial sample of spinoffs (and tracking stock issues) was retrieved from the Securities Data Corporation (SDC) Mergers and Acquisitions database. Specifically, a search for all divestitures of U.S. targets (i.e., subsidiaries)

to the parent company shareholders announced after January 1, 1985 and effective before December 31, 2001 yielded 943 transactions. From these, we eliminated 351 transactions that were announced but never completed; 144 transactions in which the subsidiary's stock was already trading in the market separately before the spinoff because of an earlier equity carve out (e.g. Agilent from Hewlett-Packard, or Lucent from AT\&T); and 98 duplicate observations 
(deals that were listed more than once in SDC). These eliminations resulted in a sample of 350 spinoffs.

Second, we used Compustat to obtain financial data for the parent and subsidiary companies in the effective years of each of these 350 spinoffs. Data on sales, assets, and market value for both the parent and subsidiary companies were available for 267 of these spinoffs. ${ }^{3}$ This number, as well as the other numbers of observations or transactions reported so far, refers to the number of new companies that were spun off. Because some transactions involve the simultaneous spinoff of more than one subsidiary by the parent (e.g. Dun \& Bradstreet’s double divestiture of A.C. Nielsen and Cognizant), the actual number of deals is lower (254). ${ }^{4,5}$

Out of the 254 deals, we randomly selected 66 as our final sample for analysis, in which four deals were double divestitures and one deal was a triple divestiture. For each of these 66 deals, we retrieved from Investext all analyst reports that were issued about the parent, the subsidiary, or both, during the time period ranging from one month prior to the announcement date to one month after the effective date. When a deal was a multiple divestiture, we selected all reports issued about the parent or any of the subsidiaries during the time period ranging from one month prior to the earliest announcement date to one month after the latest effective date. This process yielded a sample of 2,512 reports.

\footnotetext{
${ }^{3}$ In addition to SDC and Compustat CUSIPs and company names, we used information from the Center for Research on Security Prices (CRSP)-Compustat Header File, the CCH Capital Changes Reporter, and the Securities and Exchange Commission (SEC) website (which lists all former names for any given company), to maximize the number of merged SDC-Compustat observations. Whenever data were not available for the exact year of the spinoff's effective date, we used data from the latest year in which the parent company's old stock was listed in Compustat, and/or from the first year in which the spun-off company started being included in Compustat (as far as two years before or after the spinoff became effective).

${ }^{4}$ We define two or more spinoffs by the same parent as a multiple divestiture when either the announcement or the effective date was within less than a week of each other. Choosing a different threshold, e.g. a month, or five days, instead of a week, does not make a difference.

${ }^{5}$ The 267-spinoff sample included 14 such multiple divestitures-nine double divestitures and two triple divestitures for which all spun-off companies are included in the sample, plus three additional double divestitures for which one of the spun-off companies had already been eliminated at the prior stage because of an earlier carve-out.
} 
Of these 2,512 analyst reports, we subsequently eliminated those that were issued prior to the spinoff announcement date, when analysts may not have been aware that it was coming, or after the effective date, when the spun-off entity began trading as an independent company (and analysts therefore had actual stock prices to guide their analysis, which our research design seeks to avoid). Within the remaining 1,932 reports, 139 more were identified as duplicate reports and removed, leaving a final sample of 1,793 reports, or an average of 28.9 reports per spinoff. These eliminations resulted in the removal of four more deals from the sample, as all the reports on the parties to these transactions were written either before the announcement date or after the effective date. Thus, the 1,793 reports analyzed in this paper cover 62 transactions in total, representing 52 parent companies due to multiple spinoff transactions. ${ }^{6}$ Two of the parent companies, Premark International and Promus Cos., were themselves spun off from other companies earlier in our sample period. ${ }^{7}$ Table 1 lists the spinoffs included in the sample, their announcement and effective dates, and the number of analyst reports pertaining to each spinoff.

Table 2 presents summary statistics on the financial characteristics of the 52 parent companies analyzed in this paper, alongside data on the 62 subsidiaries which these firms spun off. All statistics in this table are measured as of the end of the fiscal year in which each spinoff became effective. Not surprisingly, the parent companies are significantly larger than the subsidiaries they spun off in terms of sales, total assets, and market value. However, the subsidiaries are not particularly small: their mean (median) sales are $\$ 2.2$ billion ( $\$ 1.2$ billion)_ about one fifth (one third) of the parent company sales. Parent companies do not appear to have

\footnotetext{
${ }^{6}$ All of the results that follow in this paper are identical if we eliminate the multiple-spinoff transactions and/or the tracking stock issues from our sample.

${ }^{7}$ In 1986, Kraft spun off Premark International, which ten years later spun off Tupperware. In 1990, Holiday Corp. spun off Promus Cos., which in turn spun off Promus Hotels Corp. in 1995.
} 
significantly higher leverage, profit margins, or capital expenditures than the spun-off subsidiaries.

The third and most distinctive step in our data collection process consisted of reading the 1,793 analyst reports in their entirety (10,160 pages altogether) and manually coding their content. Specifically, we gathered data about both parents and subsidiaries on the types of financial analyses conducted and valuation methods employed, the earnings and price forecasts made, the amount of detailed analysis performed about each spinoff, and analyst sentiment about the parent company's stock and about the spinoff itself. Given the magnitude of this task, we hired and trained a team of advanced undergraduate students with financial knowledge or experience to gather these data. Several steps were taken to ensure the reliability of the data they collected. First, to verify the quality of their work, the reports pertaining to several spinoffs were assigned to more than one student (unbeknownst to them), so that each student's work was crosschecked by at least one other student. When discrepancies were found, we personally checked the original analyst reports to ascertain which student was mistaken and instructed him or her to correct the mistakes in that and any other reports he or she had coded. Second, to ensure consistency across students in the way the more subjective information was coded, we had a different student go over the coding of the qualitative items across all reports. ${ }^{8}$ Third, we had three other students, including a graduate student, go over the entire data set and recode some of the quantitative items whenever serious errors, omissions, or inconsistencies became apparent.

As a final step in our data collection process, we collected data about the analysts in our sample and the investment banks or research firms they were working for at the time they issued each report. The sources of these data included Thomson's I/B/E/S; Institutional Investor

\footnotetext{
${ }^{8}$ As a further check on the validity of this data, we ran t-tests comparing the mean values of the variables coded by each pair of students, and these differences were rarely statistically significant, suggesting that inter-rater reliability was high.
} 
magazine; the IPO underwriter reputation rankings developed by Carter and Manaster (1990), Carter et al. (1998), and Loughran and Ritter (2004), which are available from Jay Ritter's website; ${ }^{9}$ Ljungqvist et al.'s (2006) graphical timeline of major investment bank mergers between 1988 and 2002; and an updated version of their chart which was published in the New York Times on September 28, 2008.

\section{Information Content of Analyst Reports about Upcoming Spinoffs}

Table 3 presents summary data on the different types of analyses conducted, methodologies employed, and sentiments expressed by the analysts who wrote the reports in our sample. These summary statistics are disaggregated according to whether an analyst provided the relevant information about the parent company, its subsidiary, or the transaction itself.

The information provided by analysts about subsidiaries is typically much sparser than the information provided about the parents, suggesting that these subsidiaries are the "forgotten child” in analysts' research. For example, the average report in our sample is 5.7 pages long, of which 3.3 pages are devoted to analyzing the parent company and less than one (0.9 pages) to analyzing its subsidiary. ${ }^{10}$ Consistent with this pattern, over $80 \%$ of all reports include an earnings-per-share (EPS) forecast for the parent, whereas over $80 \%$ of all reports include no EPS forecast for the subsidiary. Similarly, nearly half of the reports provide an EPS growth forecast and over three quarters provide a forecast of the price-to-earnings (PE) ratio for the parent, compared to about three percent of reports providing an EPS growth forecast and eight percent providing a PE forecast for the subsidiary. Finally, analysts appear to be much more likely to make other profit forecasts (such as EBITDA or net income) and financial statement for the parents than they are for the subsidiaries. In contrast to these patterns, however, analysts are

\footnotetext{
${ }^{9}$ http://bear.cba.ufl.edu/ritter/rank.pdf

${ }^{10}$ The remaining pages typically contain information about other subsidiaries in the parent company, as well as nonsubstantive information such as legal disclaimers.
} 
approximately equally likely to forecast stock prices and market capitalizations for the parents ${ }^{11}$ as they are for the subsidiaries, and in terms of valuation methods, analysts are most likely to use a PE multiple of comparable companies to value subsidiaries, just as they do for the parents.

In addition to parent- and subsidiary-specific information, reports sometimes included analyses of and sentiments expressed about the upcoming spinoff transactions. We specifically gathered data on whether each report included a discussion of six characteristics pertaining to the spinoffs: $32.9 \%$ of reports provided an analysis of the firms' competitors; $35.4 \%$ included financial information on the parent firm's business segments; $26.4 \%$ discussed the rationale for the spinoff; $13.2 \%$ mentioned the notion of a conglomerate discount; $13.8 \%$ ventured forecasts of how debt or overhead costs would be allocated in the spinoff process; and $8.4 \%$ discussed the spinoff's transaction costs.

Many prior studies have documented the near-absence of "sell" recommendations in analyst reports (e.g., Lin and McNichols, 1998; Barber et al., 2001; Morgan and Stocken 2003; Cowen et al., 2006; or Houston et al., 2006). Consistent with their findings, most of the reports in our sample expressed a favorable, or at worst, neutral opinion about the parent's stock (62\% and $25 \%$, respectively); not even $1 \%$ of reports made negative recommendations. This result is perhaps not surprising, if managers undertake spinoffs because they expect them to create value (Schipper and Smith, 1983; Hite and Owers, 1983; D’Souza and Jacob, 2000). More unique to this paper is the finding of a slightly higher dispersion in analyst sentiment about the spinoff transactions themselves: just over a third of reports expressed a positive opinion about the transactions and nearly half were neutral about them, though once again, only $1 \%$ of reports expressed a negative opinion about the spinoffs.

\footnotetext{
${ }^{11}$ Specifically, $32.7 \%$ of reports provide either a stock price forecast and/or a market capitalization forecast. Of these, $28.6 \%$ provide only a stock price forecast, $0.8 \%$ provide only a market capitalization forecast (from which it is possible to derive a price forecast), and $3.3 \%$ provide both types of forecast.
} 
Our findings about the information content of analyst reports are overall consistent with those reported by Asquith et al. (2005) and Houston et al. (2006). Both studies found, as does ours, that PE multiples are the most commonly used valuation method, followed by enterprise value multiples of sales and EBITDA, and lastly by DCF. Asquith et al. also report, as do we, that income statements are the financial statements most commonly forecasted by analysts. However, there are some differences between our findings in terms of the frequency with which similar items are reported, as can be reasonably expected from the differences in our sample selection processes. For instance, Houston et al. find price targets in $79 \%$ of reports for their sample of IPO firms during the hot market period of 1996-2000. Almost all reports in Asquith et al.'s sample contain earnings forecasts and about three-quarters contain price targets (as compared to the respective figures of $80 \%$ and $33 \%$, in our sample). ${ }^{12}$ Yet, only $10 \%$ of Asquith et al.'s sample reports contain segment financial information, as compared to $35.4 \%$ in our sample. This higher frequency can be expected since our sample companies are, by definition, conglomerates about to spin off one or more of their businesses.

What is more remarkable is how little attention analysts pay in their reports to the subsidiaries to be spun off, despite the fact that these subsidiaries are reasonably-sized entities in and of themselves. Even if analysts were not interested in covering the subsidiaries once they began trading as independent companies because of their size, industry, or some other reason, the fact that these analysts are covering the parent companies would lead one to expect greater analysis of the subsidiaries, in that their spinoffs are bound to change the parent companies'

\footnotetext{
${ }^{12}$ Asquith et al. (2005) selected a sample of reports written by Institutional Investor's All-American Research Team, which have been found to be the best in their industry both by the institutional investors who rated them and by the academic researchers who have analyzed the accuracy of their forecasts e.g., Stickel (1992). This sample selection criterion is also likely to lead to the inclusion of relatively large companies in the sample-an additional reason why we expect to find less information in our sample reports. Indeed, Asquith et al. report an average market value of equity of $\$ 16$ billion for their sample firms; the comparable figure for our sample (as can be inferred from Table 2) is $\$ 12$ billion.
} 
futures significantly. Our finding that this is not the case therefore implies that, by forgetting about the "child", analysts are somehow neglecting the parent as well.

\section{Accuracy of Analysts' Earnings and Price Forecasts around Spinoffs}

We proceed to examine how accurate analysts are at forecasting the earnings and stock prices of both parent and subsidiary companies in anticipation of spinoffs. Two earlier studies have looked at analysts' forecasting abilities around these types of deals: Krishnaswami and Subramaniam (1999) and Gilson et al. (2001). Our detailed database of actual analyst reports allows us to extend their analysis in two ways: by looking at analyst forecasts for the subsidiary as well as for the parent, and by looking at price forecasts in addition to earnings forecasts.

\subsection{Earnings Forecast Accuracy}

Following these and most other studies of analyst earnings forecast accuracy (e.g. Thomas, 2002; Agrawal et al., 2006), we measure EPS Forecast Error as the absolute value of the difference between the EPS forecasted for the subsequent year and actual EPS on the forecast date, scaled by the company's stock price. Like Gilson et al. (2001) and Agrawal et al. (2006), we measure the parent company's stock price at the end of the fiscal year prior to the forecast period for our Parent EPS Forecast Error variable. For the Subsidiary EPS Forecast Error variable, since there is no stock price available in the year prior to the forecast, we measure the subsidiary stock price at the end of the first fiscal year in which the stock trades. We further follow Agrawal et al. (2006) in eliminating outliers in which the relevant stock price used to construct this variable is less than $\$ 1$, and those for which EPS Forecast Error is greater than or equal to two. Higher values of EPS Forecast Error thus indicate that a forecast is less accurate (as the difference between the actual and forecasted values is greater), and vice versa. 
The first row in Panel A of Table 4 reports descriptive statistics for EPS Forecast Error. The mean (median) EPS Forecast Error for parent companies is 5.6\% (1.3\%). These numbers are in line with those found by prior researchers studying spinoffs, especially Krishnaswami and Subramaniam (1999), who report pre-spinoff mean (median) earnings forecast errors of $4.3 \%$ (1.1\%). Gilson et al. (2001) report mean errors of $2.82 \%$ for the last fiscal year before the spinoffs in their sample. ${ }^{13}$ By contrast, analysts tend to produce less accurate forecasts of postspinoff EPS for subsidiaries: the mean (median) EPS Forecast Error for subsidiaries is 7.5\% (3.3\%). No other study has analyzed forecast errors for subsidiaries in spinoffs. ${ }^{14}$ These univariate differences in mean (median) EPS Forecast Errors between the parent companies and their subsidiaries are statistically significant: the $t$-statistic (z-statistic) is 1.73 (3.24).

\subsection{Price Forecast Accuracy}

For symmetry with our analysis of earnings forecast accuracy, our primary measure of Price Forecast Error is constructed as the absolute value of the forecasted (target) stock price less the actual stock price on the forecast date, scaled by the company's stock price on the forecast date. As with EPS Forecast Error, higher values of Price Forecast Error indicate that analysts were less accurate in their price forecasts, and vice versa. As before, we construct this variable for all price forecasts made about parent companies (Parent Price Forecast Error) and their spun-off subsidiaries (Subsidiary Price Forecast Error).

\footnotetext{
${ }^{13}$ By construction, the forecasts in our sample were all issued before the spinoff, even though the date for which the analysts were forecasting may have been after the spinoff became effective.

${ }^{14}$ However, our findings are consistent with Thomas (2002), who reports mean forecast errors of 3.7\% for conglomerate firms and larger errors for a matched control group of single-segment firms. Although this result seems hard to reconcile with Krishnaswami and Subramaniam (1999) and Gilson et al.'s (2001) finding that earnings forecast accuracy improves significantly after conglomerate stock breakups, the explanation offered by Thomas is that even if analysts' forecast errors are larger for conglomerates than they are for focused firms, so long as those errors are imperfectly correlated, the consolidated forecast may in fact be more accurate than the forecast for a focused firm. This "information diversification" hypothesis may also be at play in our context.
} 
The first row in Panel B of Table 4 shows that the mean (median) Parent Price Forecast Error is 44\% (21\%) and the mean (median) Subsidiary Price Forecast Error is 48\% (26\%), each many times larger than the EPS forecast errors reported in Panel A. Predictably, the difference in the mean Parent Price Forecast Error is not statistically different from the mean Subsidiary Price Forecast Error (the $t$-statistic is -0.82), and the difference in medians is not statistically significantly different from zero either (the $z$-statistic is -0.44 ).

In sum, the significant differences between the accuracy of the earnings forecasts analysts make for the parent and subsidiary companies is consistent with the notion, suggested by our earlier findings in the paper, that spun-off subsidiaries are the "forgotten child" of analyst research. The lack of significant differences between parent and subsidiary price forecast errors is not surprising, however, given that stock prices are inherently more difficult to forecast than accounting performance.

\section{Impact of the Information Content of Analyst Reports on Forecast Accuracy}

In this section of the paper, we extend our analyses from the previous two sections by examining the relationship between the amount and type of research performed by analysts about upcoming spinoffs and their performance in forecasting earnings and stock prices.

\subsection{Variable Descriptions}

The dependent variables in these regressions are EPS Forecast Error and Price Forecast Error, for the parent and subsidiary companies. The independent variables we include can be broken down into five categories, discussed below, and summary statistics appear in Table 5.

The first set of variables measures the amount of attention analysts devote to companies in their reports. Total Report Pages is the total number of pages included in the report and Share of Report Pages is the proportion of pages in the report devoted to analyzing either the parent or 
subsidiary. Price Forecast is an indicator variable which takes the value one if an analyst forecasts a company's stock price. Number of Annual EPS Forecasts is a count of the number of years for which an analyst forecasts annual earnings-per-share for a company, and EPS Growth Forecast is an indicator variable taking the value one if an analyst forecasts growth in a company's EPS. Similarly, PE Forecast is an indicator variable which takes the value one if an analyst forecasts a company's P/E ratio, and Other Forecast is an indicator variable taking the value one if an analyst forecasts another accounting item or valuation ratio, e.g., revenues. Finally, Financial Statement Index is a count of the number of pro-forma financial statementsbalance sheet, income statement, and cash flow statement—included in the report. We predict that these variables will all be negatively associated with EPS Forecast Error, as analysts should make more accurate forecasts the more detail they include about a company in their reports.

The second category contains two variables representing the analysis performed about the spinoff transaction itself. Spinoff Analysis Index is a count of how many of the following six analyses analysts include in their reports: competitor analysis, segment-level financial information, rationale for the spinoff, analysis of the conglomerate discount, allocation of debt or overhead costs, and transaction costs associated with the spinoff. Days from Announcement to Report Date is defined as the number of days that have elapsed from the announcement of a spinoff to the date on which a report was written. Both of these variables should be negatively associated with EPS Forecast Error, as analysts can be expected to make more accurate forecasts when they devote more effort to analyzing an upcoming transaction.

The third category contains three control variables representing company-specific characteristics: Ln(Total Assets); Total Assets of Subsidiary / Total Assets of Parent; and Relatedness, an indicator variable taking the value one if the parent company and its spun-off 
subsidiary share a four-digit SIC code. We expect the first two of these variables to be positively associated with EPS Forecast Error, since analysts are likely to make less accurate earnings forecasts about large firms and about companies undertaking complex transactions. However, Relatedness can be expected to be negatively correlated with forecast accuracy, as analysts are likely to make more accurate forecasts when they are evaluating related businesses.

The fourth category represents the characteristics of the analysts and brokerage firms issuing the reports in our sample. Analyst Ranking by Institutional Investor (II) is a categorical variable taking the value one if an analyst is a runner-up, two if the analyst is ranked third, three if the analyst is ranked second, and four if the analyst is ranked first by Institutional Investor. ${ }^{15}$ Similarly, Broker Reputation Ranking is the underwriter reputation ranking developed by and analyzed in Carter and Manaster (1990), Carter et al. (1998), and Loughran and Ritter (2004). If these variables measure analyst and brokerage expertise, then they should be negatively associated with EPS Forecast Error; however, if they reflect something other than expertise, such as overconfidence, these variables could be positively associated with EPS Forecast Error.

To help resolve this ambiguity, we include two other variables measuring the experience analysts and brokerages have accumulated in analyzing particular industrial sectors. Analyst Provides 10\%+ of Broker's Reports in Sector is an indicator variable which takes the value one if an analyst writes $10 \%$ or more of the reports issued by his brokerage firm about firms operating in a given industrial sector. ${ }^{16}$ Analogously, Broker Provides $2 \%+$ of Reports in Sector is an indicator variable taking the value one if a brokerage firm issues $2 \%$ or more of the reports

\footnotetext{
${ }^{15}$ Analyst Ranking by II is derived from Institutional Investor Magazine, which ranks the top three analysts in several sectors, along with the runners-up, reflecting analysts' reputations in the investment community (Leone and Wu, 2007; Groysberg et al., 2008).

${ }^{16} \mathrm{I} / \mathrm{B} / \mathrm{E} / \mathrm{S}$ uses its own classification scheme, generally based on the Morgan Stanley Capital International Industry Classifications, to define the industrial sectors in which companies operate. In this system, the sector in which a firm operates is the broadest industrial definition, followed by the industry, and then the group. For example, Anheuser Busch operates in the Consumer Non-Durables sector, the Beverage industry, and the Breweries group, while Hilton Hotels operates in the Consumer Service sector, the Leisure industry, and the Hotels group.
} 
in any given industrial sector. ${ }^{17}$ In contrast to the ranking variables, these two variables reflect industrial expertise, so we expect them to be negatively correlated with EPS Forecast Error.

We also include Analyst Advisor, a count of the number of deals in the ten years preceding a spinoff in which the investment bank issuing the analyst report (or a predecessor bank that merged into it) participated as an advisor of some sort. ${ }^{18}$ This variable is included to control for the effects on forecast accuracy of brokerage firms having a prior advisory relationship with companies. If such relationships represent accumulated expertise, then Analyst Advisor should be associated with improved forecast accuracy. However, if these relationships signify conflicts of interest, then Analyst Advisor should be linked to less accurate forecasts.

Finally, the fifth category measures analyst sentiment about the upcoming spinoff. Optimistic Spinoff Spin is an indicator variable taking the value one if an analyst expressed a favorable opinion about a spinoff, suggesting that it should be negatively associated with EPS Forecast Error. Pessimistic Spinoff Spin is an indicator variable which takes the value one if an analyst expressed an unfavorable opinion about a spinoff, suggesting that it should be positively related to EPS Forecast Error. ${ }^{19}$

\subsection{Analyst Research and Earnings Forecast Accuracy}

Table 6 presents the results of ordinary least squares regressions in which the dependent variables are Parent EPS Forecast Error in Regression [1] and Subsidiary EPS Forecast Error in Regression [2]. The independent variables described in the previous subsections, as well as

\footnotetext{
17 The thresholds of $10 \%$ and $2 \%$ were chosen, respectively, to calculate Analyst Provides $10 \%+$ of Broker's Reports in Sector and Broker Provides 2\%+ of Reports in Sector because they were the median values in the distributions of these two variables. Our results are not sensitive to either of these two cutoffs.

18 "Deals" include mergers and acquisitions, spinoffs, divestitures, and equity issues (both IPOs and SEOs). Data for this variable were gathered from Thomson One and Capital IQ.

${ }^{19}$ Both of these variables take the value zero if an analyst expressed a neutral or no opinion about a spinoff.
} 
year fixed effects, are included in these models. Robust standard errors are clustered at the analyst level to account for intra-group correlation among reports written by the same analyst.

In Regression [1], the relations between Parent EPS Forecast Error and the independent variables are generally as predicted. The coefficients on Fraction Parent Pages, Number of Annual Parent EPS Forecasts, and Other Parent Forecast are all negative and significant, suggesting that when analysts devote more attention to parent companies, they make more accurate forecasts about them. The coefficient on Parent Financial Statement Index is positive and significant, suggesting that the more financial statements analysts project, the less accurate their forecasts. ${ }^{20}$ Days from Announcement to Report Date is negative and statistically significant, indicating that analysts make more accurate forecasts the greater the amount of time elapsed between the announcement and report dates. Ln(Total Assets of Parent) and Total Assets of Subsidiary / Total Assets of Parent are positive and statistically significant, meaning that analysts make less accurate forecasts about larger firms and firms involved in more complex transactions. By contrast, the coefficient on Relatedness is negative and statistically significant, suggesting that analysts make more accurate forecasts about a parent company when it is related to the segment it is about to spin off.

The coefficients on the two "ranking" variables, Analyst Ranking by II and Broker Reputation Ranking, are both positive and significant. Consistent with the earlier discussion, the signs of these coefficients suggest that these ranking schemes may reflect something other than analyst or brokerage firm expertise. By contrast, the coefficients on Analyst Provides 10\%+ of Broker's Reports in Sector and Broker Provides 2\%+ of Reports in Sector are both negative and

\footnotetext{
${ }^{20}$ While this result may seem counterintuitive at first, it is likely to be attributable to some omitted variable that is positively associated both with forecast errors and with analysts' propensity to forecast financial statements, such as the noisiness of the environment. Consistent with this explanation, DeFond et al. (2003) find that analysts are more likely to forecast cash flows for firms that have high earnings volatility.
} 
statistically significant, meaning that industry experience is indeed linked to improved forecast accuracy. Additionally, the coefficient on Analyst Advisor is negative and significant, indicating that prior advisory relationships are also correlated with improved forecast accuracy. Finally, the coefficient on Optimistic Spinoff Spin is negative and significant, suggesting that analysts make more accurate forecasts about a company when they have expressed a favorable opinion about its spinoff. The coefficient on Pessimistic Spinoff Spin is positive, though it is not statistically significant. $^{21}$

Regression [2], in which the dependent variable is Subsidiary EPS Forecast Error, tells a dramatically different story. The only significant variable representing the contents of the analyst report is Subsidiary Price Forecast, whose coefficient is negative and significant, suggesting that analysts make more accurate earnings forecasts for subsidiaries when they include a price forecast in their analyses. Additionally, the coefficient on Days from Announcement to Report Date is negative and significant, again indicating that analysts make more accurate forecasts when more time elapses after the announcement date. The coefficient on Ln(Total Assets of Subsidiary) is again positive and significant, suggesting that analysts make less accurate earnings forecasts for larger subsidiaries. The coefficient on Broker Provides $2 \%+$ Reports in Sector is positive and significant, suggesting that the industrial expertise of a brokerage is related to less accurate forecasts, potentially because this industry expertise is specialized to the parent, not the subsidiary. Finally, the coefficient on Analyst Advisor is negative and significant, indicating that previous advisory relationships are again correlated with more accurate earnings forecasts.

It is important to highlight two major differences between these subsidiary-level results and the parent company results. First, many fewer variables are significant in the subsidiary

\footnotetext{
${ }^{21}$ We find similar results when we replace these two "spinoff spin” variables with analogous variables for analysts" stock recommendations: positive recommendations are associated with more accurate forecasts, and negative recommendations with less accurate forecasts.
} 
regression than were in the parent company regression. Second, and more strikingly, the significant variables in the subsidiary regression pertain to analyst and company characteristics, not to the contents of the reports. In the parent company regression, however, both types of variables are related to forecast accuracy. These two differences are consistent with our earlier depiction of subsidiaries as the "forgotten children" of companies covered in analyst reports.

\subsection{Controlling for Unobserved Heterogeneity and Selection Bias}

One potential concern with the foregoing results is that they do not fully account for the possibility that the observations are not truly independent of one another. While the standard errors in the regressions in the previous subsection are clustered at the analyst level, an additional way of accounting for this concern is to include analyst fixed effects and thus correct the estimates for unobserved heterogeneity. ${ }^{22}$ Table 7 presents the fixed effects regression results.

As before, Regression [1] in Table 7 takes Parent EPS Forecast Error as its dependent variable, while Regression [2] uses Subsidiary EPS Forecast Error. The number of significant coefficients falls in both regressions, suggesting that analyst fixed effects explain a portion of the variation. Nevertheless, many of the same variables in Regression [1], the parent firm regression, remain statistically significant. By contrast, none of the coefficients in Regression [2] is statistically significant, lending further support to our finding that subsidiaries appear to be the forgotten children of analyst reports.

A second potential concern with the results presented in the preceding subsection is that they may be driven by the effects of selection: of the 1,793 reports comprising our sample, 1,400 of them include EPS forecasts for the parent companies and only 263 of them provide such forecasts for the subsidiaries. As a result, the factors driving analysts to include EPS forecasts in

\footnotetext{
${ }^{22}$ It would not be appropriate to include firm or deal fixed effects because they would entirely swamp the variation across analysts - the key unit of analysis in this work - as we are primarily interested in what analysts include in their models and how these items influence analysts' forecast accuracy.
} 
their reports may be correlated in unobserved ways with their ability, or lack thereof, to make accurate forecasts. Thus, it becomes desirable to rule out this possibility by using Heckman twostage models instead of ordinary least squares regressions.

Heckman's estimator requires an exclusion restriction, i.e., at least one (instrumental) variable that is correlated with analysts' propensities to include EPS forecasts in their reports but not with the accuracy of those forecasts, and which should thus be included in the first-stage specification but rightfully excluded from the second. We propose and use as our instrument Subsidiary IPO / Parent IPO, the ratio of the dollar value of IPO issues in the subsidiary's industry to the dollar value of IPO issues in the parent's industry, both measured in the year in which each analyst report was written.

The logic behind this instrument is as follows. We expect Subsidiary IPO / Parent IPO to be correlated with EPS Forecast, in that analysts should be more likely to include greater detail in their coverage of companies operating in “hot” industries (O’Brien and Bhushan, 1990; Rajan and Servaes, 1997) More specifically, we predict a negative relation between this instrument and Parent EPS Forecast, because analysts will be more likely to include an EPS forecast about a parent company when it operates in a more active industry, represented by smaller values of Subsidiary IPO / Parent IPO. Analogously, we expect a positive relation between the instrument and Subsidiary EPS Forecast, as analysts will be more likely to make EPS forecasts about subsidiaries operating in more active industries, as reflected by higher values of Subsidiary IPO / Parent IPO. In contrast to these hypothesized relationships, however, there is no direct mechanism that we are aware of that would systematically link the relative volume of new equity issues in particular industries to the accuracy of analyst's EPS forecasts, so our instrument also satisfies the exclusion restriction. 
Table 8 presents the results of the Heckman regressions. Regression [1] presents the results of a regression taking Parent EPS Forecast Error as the dependent variable in the second-stage model and Parent EPS Forecast as the dependent variable in the first-stage model. In Regression [2], Subsidiary EPS Forecast Error is the dependent variable in the second-stage model and Subsidiary EPS Forecast is the dependent variable in the first-stage model. In both regressions, Subsidiary IPO / Parent IPO is the instrument included in the first-stage models.

In both Regressions [1] and [2], the results of the second-stage models remain quite similar to the results of the ordinary least squares models. Importantly, Subsidiary IPO / Parent IPO behaves exactly as it was expected to, with a negative and highly significant coefficient in the first-stage model pertaining to Regression [1] and a positive and significant coefficient in the first-stage model pertaining to Regression [2]. All in all, the results in this table suggest that our earlier findings are not attributable to selection.

\subsection{Forgotten Children, Neglected Parents?}

Thus far, we have established that analysts provide little information in their reports about subsidiaries which will be spun off from their corporate parents, and this inattention affects the accuracy of their forecasts in at least two ways: first, analysts make less accurate earnings forecasts for the subsidiaries than for their parents, and second, the amount and type of analyst research is much less relevant to earnings forecast accuracy for the subsidiaries than it is for the parents.

At a first glance, the fact that analysts pay less attention to the subsidiaries than to the parents themselves can hardly be seen as surprising, since analysts have a mandate to cover the parents. However, given the size and strategic significance of many of these subsidiaries, a thorough analysis of the parent's future performance would seem to require greater attention to 
the subsidiaries about to be spun off. In this subsection, we directly test whether analysts' abilities to make accurate earnings forecasts about parent companies are hindered by their inattention to the subsidiaries.

We explore this issue by including the Subsidiary EPS Forecast Error variable as an independent variable in the Parent EPS Forecast Error regression developed in the previous subsections. Because analysts only make EPS forecasts for subsidiaries in 263 of the 1,793 reports (as compared to 1,400 reports including parent EPS forecasts), we again use a two-stage Heckman model to account for the effects of this selection process.

In this specification, the first-stage regression predicts analysts' propensity to make a subsidiary EPS forecast and therefore takes Subsidiary EPS Forecast as its dependent variable. The independent variables in that regression are the same as the variables used in the first-stage of the subsidiary Heckman model (Regression [2]) in Table 8, including the instrumental variable, Subsidiary IPO / Parent IPO. The second-stage regression predicts parent earnings forecast accuracy, and therefore takes Parent EPS Forecast Error as its dependent variable. The key independent variable in this model is Subsidiary EPS Forecast Error, corrected for selection due to missing observations by the Heckman estimator. The other independent variables in this second-stage regression are the same as those included in the second-stage of the parent Heckman model (Regression [1]) in Table 8.

We present the results of this two-stage model in Table 9. The variables in the first-stage model behave as they did previously, in particular the instrumental variable, Subsidiary IPO / Parent IPO, which remains positively and significantly related to Subsidiary EPS Forecast. More importantly, in the second-stage regression, the coefficient on Subsidiary EPS Forecast Error is positively and significantly associated with Parent EPS Forecast Error, meaning that 
when analysts make less accurate forecasts about the subsidiaries that will be spun off, they also make less accurate forecasts about their parents. To rule out the possibility that our results are due to simple correlation between parent and subsidiary EPS forecast errors, we ran the opposite regression, including Parent EPS Forecast Error as an independent variable in a regression taking Subsidiary EPS Forecast Error as its dependent variable; in that model, the coefficient on Parent EPS Forecast Error is not statistically significant. Thus, our result provides support for the notion that by forgetting about subsidiaries, analysts also neglect the parents.

\subsection{Analyst Research and Price Forecast Accuracy}

We conclude this section of the paper by briefly turning our attention to the impact of analyst research on the accuracy of price forecasts for both parent and subsidiary companies. The dependent variable is now Price Forecast Error, which we calculate as before. Since higher values of Price Forecast Error reflect lower accuracy, a negative coefficient for an information item signifies that such information is associated with more accurate forecasts, and vice versa.

Table 10 presents the results of regressions evaluating price forecast accuracy; Regression [1] takes Parent Price Forecast Error as its dependent variable and Regression [2] uses Subsidiary Price Forecast Error as its dependent variable. All of the independent variables are the same as the ones employed in the previous section of the paper, except for Price Forecast, which is now excluded. As we did previously, we include year fixed effects, as well as robust standard errors clustered at the analyst-level to account for intra-group correlation.

In Regression [1], the coefficient on EPS Growth Forecast is negative and significant, indicating that when analysts include an EPS growth forecast in their reports, they tend to make more accurate price forecasts. The coefficient on Spinoff Analysis Index is positive and significant, suggesting that more detailed analyses of spinoff transactions are associated with less 
accurate price forecasts. Finally, the coefficients on Ln(Total Parent Assets) and on Analyst Ranking by II are both negative and significant, in contrast to our findings in the EPS models.

In Regression [2], the coefficients on Other Subsidiary Forecast and Days from Announcement to Report Date are both negative and statistically significant, indicating that when analysts include a profit forecast or have more time to evaluate an upcoming spinoff, they make more accurate price forecasts for the subsidiary. The coefficient on Subsidiary Financial Statement Index is positive and significant, meaning that analysts make less accurate price forecasts the greater the number of subsidiary financial statements they attempt to forecast.

To analyze the sensitivity of our results about price forecast accuracy to the measures and statistical methods we use, we conduct two additional robustness checks. First, we replace Price Forecast Error with the measure of price forecast accuracy employed by Asquith et al. (2005), described in the second row of Panel B in Table 4. Second, just as we did in our analysis of earnings forecast errors, we employ analyst fixed effects and Heckman models (using Subsidiary $I P O$ / Parent IPO as the instrument) instead of ordinary least squares regressions. In both cases, our results are qualitatively unchanged.

Overall, many fewer coefficients are significant in the Price Forecast Error regressions than were in the EPS Forecast Error models, and once again, this is particularly true in the subsidiary regression. This finding seems to suggest that the types of projections analysts include in their reports are less helpful to them in making price forecasts than they are in making EPS forecasts, especially in the case of the subsidiaries. The result is also consistent with the fact that stock prices are inherently more difficult to predict than accounting earnings. 


\section{Comparing Spinoffs to Other Complex Transactions}

Thus far, we have established that analysts provide less information about subsidiaries that will be spun-off than they do about their parents, and this inattention is associated with less accurate earnings forecasts for the subsidiaries and in turn, for the parent companies. The outstanding question is why analysts do not seem to add more value in a context where their potential to do so seems large. One possible explanation is that spinoffs may be an especially difficult context for analysts to evaluate.

We investigate this possibility by comparing the earnings forecast errors in our sample with those reported in studies of other complex situations. As discussed previously (and shown in Panel A of Table 4), the mean (median) EPS Forecast Error for the parent companies in our sample is $5.6 \%$ (1.3\%), and for the subsidiaries, it is 7.5\% (3.3\%). Rajan and Servaes (1997) examine analyst EPS forecast errors for IPOs and find that the average errors range from 3.4\% for a three-month window to $5.8 \%$ for a 12 -month window after the IPO. Clement et al. (2007) study analyst forecasting performance within the context of firms that experience restructuring charges from downsizing (e.g., costs of closing plants, selling off assets, or terminating employees) and report mean earnings forecast errors of 5\%. In these cases, the earnings forecast estimates in the context of our sample of spinoffs appear to be less accurate than those in the other complex situations, suggesting that the complexity of spinoffs relative to other types of restructuring may indeed be linked to analysts' inattention to subsidiaries.

This point is further corroborated by comparing forecast error estimates from studies of mergers to our sample of spinoffs. On the one hand, in principle, a merger (where one plus one equals two) is the reverse of a spinoff (where two minus one equals one), suggesting that analysts should have equal ease or difficulty in making accurate earnings forecast estimates for 
the two types of transactions. On the other hand, because of the intricate links that may have developed over time across a firm's different businesses, combined with the challenges of debt and overhead allocation among the parts of the former whole, spinoffs may turn out to be more complex to analyze than mergers.

Haw et al. (1994) study the accuracy of analyst earnings forecasts around mergers and find mean (median) absolute forecast errors relative to actual EPS (instead of relative to price) of $19 \%(10 \%)$ in the year before the merger, and 29\% (14\%) in the year after the merger. However, the second row in Panel A of Table 4 shows that the mean (median) earnings forecast error (computed relative to actual EPS rather than to price), is $34.58 \%$ (11.30\%) for the parent companies in our sample and 51.25\% (44.44\%) for the subsidiaries. Clearly, the forecast error estimates from our sample of spinoffs far exceed the forecast error estimates from Haw et al.'s sample of mergers, suggesting that spinoffs exhibit a greater degree of complexity than the reverse type of transaction.

To substantiate our point still further, we also undertake comparisons of the price forecasts made in our sample of spinoffs to those made in the context of other complex transactions. To facilitate comparison with the few studies that have analyzed price forecast accuracy, we report in Panel B of Table 4 price forecast errors measured in two alternative ways.

First, following Gilson et al. (2000), we measure price forecast errors as the natural logarithm of the ratio of the forecasted stock price to the actual stock price (Line 2 in Panel B of Table 4), and find mean (median) errors of $42.86 \%$ (23.50\%) for the parent and $42.17 \%$ (31.60\%) for the subsidiary. Gilson et al. (2000) compare the valuation of bankrupt firms that outside investors or researchers can perform using earnings forecasts published by management or financial analysts, with the actual market value of those firms. The mean (median) price 
forecast errors they report are $-0.5 \%(9.9 \%)$ using a discounted capital cash flow valuation model, and 3.6\% (3.0\%) using multiples of comparable companies. ${ }^{23}$ Clearly, these figures fall far short of the estimates from our sample.

Second, following Asquith et al. (2005), we calculate the percentage of analyst reports whose price forecasts were attained or surpassed by the actual stock price at any time during the 12-month period following the release of the report, and estimate the maximum (minimum) percentage of the price target attained by the actual stock price during those 12 months, when the price target was set above (below) the stock price on the report date (Line 3 in Panel B of Table 4). We find that $66 \%$ (46\%) of the reports that contained parent (subsidiary) price forecasts had those forecasts attained or surpassed by the actual stock price, which they did by an average of 47\% (28\%). For the remaining 34\% (54\%) of reports whose forecasts were never met within 12 months, the actual stock price fell short of attaining the forecast by an average of $20 \%$ (27\%). In contrast, 54\% of the reports in Asquith et al.'s (2005) sample saw their forecasts attained or surpassed, by an average of $37 \%$, and in the remaining $46 \%$, the actual price missed the target by an average of $16 \%$. The larger margin of error we find in our sample is consistent with the fact that spinoffs are unusually complex situations, whereas the forecasts in Asquith et al. (2005) were made in the regular course of business for the firms in their sample.

Overall, our examination of analyst forecasting performance and the comparison with earlier results from a variety of different settings suggests that the challenge analysts face in forecasting earnings around spinoffs is larger than that encountered in other "special situations"

\footnotetext{
${ }^{23}$ Kaplan and Ruback (1995) perform a similar comparison in the context of highly leveraged transactions and report similarly measured mean valuation errors that range between $0.3 \%$ and $-17 \%$ depending on the valuation method used. However, their study relies only on management forecasts as published in legal filings, not on analyst forecasts, and is therefore less relevant here. Houston et al. (2006) run regressions of IPO actual offer price to sales ratios on price to sale ratios estimated using the same comparable companies used by analysts to set target prices when they initiate coverage of the IPO firm and find that the estimated values only explained about $30 \%$ of the variation in IPO offer prices in their sample. However, they do not report valuation errors, thus their results cannot be directly compared to ours.
} 
such as IPOs, mergers, bankruptcies, and other forms of corporate restructuring. Forecasting stock prices for parent and subsidiary companies subsequent to a spinoff seems particularly difficult, perhaps because spinoffs are the only context in which there is absolutely no price history for the subsidiaries that need to be analyzed. ${ }^{24}$

\section{Conclusion}

In this paper we investigate equity analysts’ coverage of pending corporate spinoffs, and analyze whether equity analysts provide investors with useful information about the valuation consequences of these transactions. Spinoffs provide an interesting context in which to study the information content of analysts' research, because the degree of information asymmetry between corporate insiders and investors is especially high in these situations. Analysts who have followed these firms for an extended time prior to the completion of these spinoffs should have a comparative advantage in forecasting the future stand-alone performance of the parent and subsidiary companies, and in assessing how the spinoffs might impact firms' market values. At the same time, however, these restructurings are complex, and they may coincide with significant changes in firms' strategies or markets, potentially limiting analysts' ability to generate useful information for investors.

We use manually collected data from 1,793 analyst reports that were issued around 62 spinoffs and tracking stock issues to provide detailed empirical evidence about the quantity, type, and quality of research performed by analysts. We find that analysts pay relatively little attention in their reports to the subsidiaries that will be spun off (measured, for example, by page counts, or by whether the reports include explicit forecasts of post-spinoff EPS), even though

\footnotetext{
${ }^{24}$ Even in newly public companies, analysts have a minimum price history of 25 days (or 40, since 2002) as a reference, because of the quiet period that has to be observed after any IPO.
} 
subsidiaries generally account for an economically significant share of firms' operations before the spinoff—a result we label as "the forgotten child effect."

Consistent with this lack of attention to subsidiaries, we find that when analysts do provide forecasts of subsidiary EPS, the forecasts are less accurate than corresponding parent EPS forecasts. Analysts' forecasts of post-spinoff stock prices for both parents and subsidiaries tend to be less accurate than their EPS forecasts. We show that forecasts of parent EPS are more accurate when analysts or their investment banks have more experience covering the firm or its industry, and when analysts pay relatively more attention to and provide more detailed information about the parent in their reports. Similar cross-sectional variation is not observed in the case of subsidiary EPS forecast errors, however. Moreover, we establish that when analysts make less accurate forecasts about subsidiaries, they in turn make less accurate forecasts about their parents, providing evidence that by forgetting about the child in their reports, analysts also neglect the parent companies.

Finally, we illustrate that both the EPS and price forecast errors in our sample of spinoffs exceed forecast errors previously documented in the context of other corporate restructuring transactions, such as IPOs, mergers, and bankruptcies. We conclude that the complexity associated with forecasting earnings and stock prices in the context of corporate spinoffs, combined with analysts' apparent disregard for subsidiaries in their analysis of corporate spinoffs, seem to limit analysts' ability to add value as information intermediaries in this setting. 


\section{References}

Agrawal, Anup, Sahiba Chadha, and Mark Chen, 2006, Who is Afraid of Reg FD? The Behavior and Performance of Sell-Side Analysts Following the SEC's fair Disclosure Rules, Journal of Business 79, 2811-2834.

Agrawal, Anup and Mark Chen, 2008, Do Analyst Conflict Matter? Evidence from Stock Recommendations, Journal of Law and Economics 51, 503-537.

Asquith, Paul, Michael Mikhail, and Andrea Au, 2005, Information Content of Equity Analyst Reports, Journal of Financial Economics, 75, 245-282.

Barber, Brad, Reuven Lehavy, Maureen McNichols, and Brett Trueman, 2001, Can Investors Profit from the Prophets? Security Analyst Recommendations and Stock Returns, Journal of Finance 56, 531-563.

Berger, Philip G., and Eli Ofek, 1995, Diversification's effect on firm value, Journal of Financial Economics 37, 39-65.

Carter, Richard, Frederick Dark, and Ajay Singh, 1998, Underwriter Reputation, Initial Returns, and the Long-run Performance of IPO Stocks, Journal of Finance 53, 285-311.

Carter, Richard, and Steven Manaster, 1990, Initial Public Offerings and Underwriter Reputation, Journal of Finance 45, 1045-1068.

Clement, Michael, Lisa Koonce, and Thomas Lopez, 2007, The roles of task-specific forecasting experience and innate ability in understanding analyst forecasting performance, Journal of Accounting and Economics 44, 378-398.

Cowen, Amanda, Boris Groysberg, and Paul M. Healy, 2006, Which types of analyst firms make more optimistic forecasts? Journal of Accounting and Economics 41, 119-146.

DeFond, Mark, and Mingyi Hung, 2003, An Empirical Analysis of Analysts' Cash Flow Forecasts, Journal of Financial Economics, 35, 73-100.

D’Souza, Julia, and John Jacob, 2000, Why Firms Issue Targeted Stock, Journal of Financial Economics 56, 459-483.

Francis, J., Soffer, L., 1997, The relative informativeness of analysts' stock recommendations and earnings forecast revisions, Journal of Accounting Research 35, 193-211.

Gilson, Stuart, 1994, Humana, Inc.: Managing in a changing industry, Harvard Business School Case 294-062.

Gilson, Stuart, 2000, Analysts and information gaps: Lessons from the UAL buyout, Financial Analysts Journal, Nov.-Dec., 82-110.

Gilson, Stuart, Paul Healy, Christopher Noe, and Krishna Palepu, 2001, Analyst specialization and conglomerate stock breakups, Journal of Accounting Research 39, 565-582.

Gilson, Stuart, Edith Hotchkiss, and Richard Ruback, 2000, Valuation of bankrupt firms, Review of Financial Studies 13, 43-74.

Gintschel, Andreas, and Stanimir Markov, 2004, The Effectiveness of Regulation FD. Journal of Accounting and Economics 37, 293-314. 
Givoly, Dan, and Josef Lakonishok, 1979, The information content of financial analysts' forecasts of earnings, Journal of Accounting and Economics 1, 165-185.

Gleason, Cristi A., and Charles M.C. Lee, 2003, Analyst forecast revisions and market price discovery, The Accounting Review 78, 193-225.

Gomes, Armando, Gary Gorton and Leonardo Madureira, 2007, SEC Regulation FD, Information, and the Cost of Capital, Journal of Corporate Finance 13, 300-334.

Groysberg, Boris, Paul Healy, and Craig Chapman, 2008, Buy-Side vs. Sell-Side Analysts' Earnings Forecasts, Financial Analysts Journal 64, 25-39.

Haw, In-Mu, Kooyul Jung, and William Ruland, 1994, The accuracy of financial analysts' forecasts after mergers, Journal of Accounting, Auditing, and Finance 9, 465-486.

Hite, Gailen, and James Owers, 1983, Security Price Reactions Around Corporate Spin-Off Announcements, Journal of Financial Economics 12, 409-436.

Hong, Harrison, Terence Lim, and Jeremy Stein, 2000, Bad News Travels Slowly: Size, Analyst Coverage and the Profitability of Momentum Strategies, Journal of Finance 60, 265-295.

Houston, Joel, Christopher James, and Jason Karceski, 2006, What a Difference a Month Makes: Stock Analyst Valuations Following Initial Public Offerings, Journal of Financial and Quantitative Analysis 41, 111-137.

Jegadeesh, Narasimhan, Joonghyuk Kim, Susan D. Krische, and Charles Lee, 2004, Analyzing the analysts: When do recommendations add value?, Journal of Finance 59, 1083-1124.

Kadan, Ohad, Leonardo Madureira, Rong Wang, and Tzachi Zach, 2009, Conflicts of Interest and Stock Recommendations - the Effect of the Global Settlement and Related Regulations, Review of Financial Studies 22, 4189-4217.

Kaplan, Steven, and Richard Ruback, 1995, The valuation of cash flow forecasts: An empirical analysis, Journal of Finance 50, 1059-1093.

Kelly, Brian, and Alexander Ljungvist, 2008, The value of research, working paper, New York University.

Kolasinski, Adam and S.P. Kothari, 2008, Investment Banking and Analyst Objectivity: Evidence from Analysts Affiliated with Mergers and Acquisition Advisors, Journal of Financial and Quantitative Analysis 43, 817-842.

Krishnaswami, Sudha, and Venkat Subramaniam, 1999, Information Asymmetry, Valuation, and the Corporate Spin-off Decision, Journal of Financial Economics 53, 73-112.

Leone, Andrew, and Joanna Shuang $\mathrm{Wu}, 2007$, What does it Take to Become a Superstar? Evidence from Institutional Investor Rankings of Financial Analysts, Working paper.

Lin, Hsiou-wei, and Maureen McNichols, 1998, Underwriting relationships, analysts' earnings forecasts and investment recommendations, Journal of Accounting and Economics 25, 101-127.

Ljungvist, Alexander, Felicia Marston, and William Wilhelm, 2006, Competing for Securities Underwriting Mandates: Banking Relationships and Analyst Recommendations, Journal of Finance 61, 301-340. 
Loughran, Tim, and Jay Ritter, 2004, Why has IPO underpricing changed over time? Financial Management 33, 5-37.

Michaely, Roni, and Kent Womack, 1999. Conflict of interest and the credibility of underwriter analyst recommendations, The Review of Financial Studies 12, 653-686.

Morgan, John, and Phillip Stocken, 2003, An Analysis of Stock Recommendations, RAND Journal of Economics 34, 183-203.

O’Brien, Patricia, and Ravi Bhushan, 1990, Analyst Following and Institutional Ownership, Journal of Accounting Research 28, 55-76,

Rajan, Raghuram, and Henri Servaes, 1997, Analyst Following of Initial Public Offerings, Journal of Finance 52, 507-529.

Schipper, Katherine, and Abbie Smith, 1983, Effects of Recontracting on Shareholder Wealth: The Case of Voluntary Spin-Offs, Journal of Financial Economics 12, 437-467.

Stickel, Scott E., 1992, Reputation and Performance among Security Analysts, Journal of Finance 47, 1811-1836.

Thomas, Shawn, 2002, Firm diversification and asymmetric information: Evidence from analysts' forecasts and earnings announcements, Journal of Financial Economics 64, 373-396.

Zuckerman, Ezra W., 1999, The Categorical Imperative: Securities Analysts and the Illegitimacy Discount, American Journal of Sociology 104, 1398-1438. 


\section{Table 1. Spinoffs Included in the Sample}

List of spinoffs and tracking stock issues included in a random sample of 62 refocusing transactions announced between 1985 and 2000.

\begin{tabular}{|c|c|c|c|c|}
\hline $\begin{array}{c}\begin{array}{c}\text { Number } \\
\text { of }\end{array} \\
\text { Analyst } \\
\text { Reports }\end{array}$ & $\begin{array}{c}\text { Announcement } \\
\text { Date }\end{array}$ & $\begin{array}{l}\text { Effective } \\
\text { Date }\end{array}$ & Parent Company Name & Subsidiary Company Name \\
\hline 4 & 12/2/1992 & 12/26/1992 & Adolph Coors & ACX Technologies \\
\hline 4 & 8/23/1988 & 11/30/1988 & Ametek & Ketema \\
\hline 44 & 7/26/1995 & $3 / 27 / 1996$ & Anheuser-Busch & Earthgrains \\
\hline 184 & 9/20/1995 & 12/31/1996 & AT\&T & NCR \\
\hline 7 & 6/27/1995 & $1 / 4 / 1996$ & Bally Entertainment & Bally's Health \& Tennis \\
\hline 12 & 4/27/1992 & 12/1/1992 & Baxter International & Caremark \\
\hline 104 & 7/12/1999 & $3 / 31 / 2000$ & Baxter International & Edwards Lifesciences \\
\hline 3 & $4 / 23 / 1985$ & $4 / 10 / 1986$ & Borg-Warner & York International \\
\hline 113 & $9 / 28 / 2000$ & $8 / 6 / 2001$ & Bristol-Myers Squibb & Zimmer Holdings $^{1}$ \\
\hline 25 & 9/9/1997 & 3/30/1998 & Campbell Soup & Vlasic Foods International \\
\hline 48 & $7 / 18 / 2000$ & 3/30/2001 & Ceridian & Arbitron \\
\hline 10 & 8/26/1996 & 12/3/1996 & $\begin{array}{l}\text { Consolidated Freightways } \\
\text { (renamed CNF Transportation) }\end{array}$ & Consolidated Freightways \\
\hline 5 & 3/29/1988 & 10/7/1988 & Crane & Medusa \\
\hline 35 & $1 / 9 / 1996$ & $11 / 1 / 1996$ & Dun \& Bradstreet & ACNielsen $^{2}$ \\
\hline 18 & $1 / 9 / 1996$ & $11 / 1 / 1996$ & Dun \& Bradstreet & Cognizant $^{2}$ \\
\hline 25 & 12/16/1999 & $10 / 3 / 2000$ & Dun \& Bradstreet & Moody's Investors Service \\
\hline 54 & $6 / 15 / 1993$ & $1 / 4 / 1994$ & Eastman Kodak & Eastman Chemical \\
\hline 15 & $6 / 8 / 2000$ & $12 / 1 / 2000$ & Fluor (renamed Massey) & Fluor \\
\hline 54 & $4 / 14 / 2000$ & $6 / 28 / 2000$ & Ford Motor & Visteon \\
\hline 9 & $1 / 7 / 1997$ & $7 / 23 / 1997$ & General Instrument & CommScope $^{2}$ \\
\hline 9 & $1 / 7 / 1997$ & $7 / 28 / 1997$ & General Instrument & NextLevel Systems ${ }^{2}$ \\
\hline 17 & $4 / 25 / 1985$ & $11 / 29 / 1985$ & General Mills & Crystal Brands ${ }^{2}$ \\
\hline 35 & $12 / 15 / 1994$ & $5 / 10 / 1995$ & General Mills & Darden Restaurants \\
\hline 17 & $4 / 25 / 1985$ & $11 / 29 / 1985$ & General Mills & Kenner Parker Toys ${ }^{2}$ \\
\hline 34 & 3/4/1999 & 6/28/1999 & Genzyme & Genzyme Surgical Products ${ }^{3}$ \\
\hline 12 & 9/17/1997 & 12/16/1997 & Georgia-Pacific & Georgia-PacificTimber ${ }^{3}$ \\
\hline 12 & 10/11/1995 & 1/24/1996 & Halliburton & Highlands Insurance Group \\
\hline 2 & 9/15/1993 & $12 / 16 / 1993$ & Harcourt General & GC Cos. (General Cinema) \\
\hline 26 & 6/30/1998 & 12/31/1998 & Hilton Hotels & Park Place Entertainment \\
\hline 13 & 8/24/1989 & 2/7/1990 & Holiday & Promus \\
\hline 11 & $4 / 17 / 1990$ & $10 / 3 / 1990$ & Honeywell & Alliant Techsystems \\
\hline 7 & 8/9/1995 & $12 / 26 / 1995$ & Host Marriott & Host Marriott Services \\
\hline 5 & 8/27/1992 & 3/8/1993 & $\begin{array}{l}\text { Humana (renamed Galen Health } \\
\text { Care ) }\end{array}$ & Humana \\
\hline 12 & $12 / 8 / 1993$ & 3/4/1994 & ITT & Rayonier \\
\hline 8 & $6 / 15 / 2000$ & $7 / 13 / 2000$ & Kansas City Southern Industries & Stilwell Financial \\
\hline 9 & 6/19/1986 & 10/27/1986 & Kraft & Premark International \\
\hline 17 & 6/18/1993 & $3 / 17 / 1994$ & Litton Industries & Western Atlas \\
\hline 114 & $3 / 1 / 2000$ & $10 / 2 / 2000$ & Lucent Technologies & Avaya \\
\hline 7 & $11 / 7 / 1986$ & $4 / 28 / 1987$ & Lucky Stores & Hancock Fabrics \\
\hline 26 & 1/17/1996 & 5/9/1996 & May Department Stores & Payless ShoeSource \\
\hline
\end{tabular}


Table 1. Spinoffs Included in the Sample (continued)

\begin{tabular}{|c|c|c|c|c|}
\hline $\begin{array}{c}\begin{array}{c}\text { Number } \\
\text { of }\end{array} \\
\text { Analyst } \\
\text { Reports }\end{array}$ & $\begin{array}{c}\text { Announcement } \\
\text { Date }\end{array}$ & $\begin{array}{c}\text { Effective } \\
\text { Date }\end{array}$ & Parent Company Name & Subsidiary Company Name \\
\hline 40 & 11/14/1995 & 7/1/1996 & $\begin{array}{l}\text { Minnesota Mining \& } \\
\text { Manufacturing (3M) }\end{array}$ & Imation \\
\hline 21 & 2/27/1989 & 7/3/1989 & $\begin{array}{l}\text { Morton-Thiokol (renamed } \\
\text { Thiokol) }\end{array}$ & Morton International \\
\hline 4 & 9/5/1996 & 12/31/1996 & Murphy Oil & Deltic Timber \\
\hline 18 & 3/9/1999 & 6/15/1999 & Nabisco Group Holdings & RJ Reynolds Tobacco Holdings \\
\hline 2 & 9/23/1998 & 4/27/1999 & PE Biosystems & Celera Genomics ${ }^{3}$ \\
\hline 99 & $1 / 23 / 1997$ & 10/7/1997 & PepsiCo & Tricon Global Restaurants \\
\hline 16 & 11/1/1995 & 5/31/1996 & Premark International & Tupperware \\
\hline 31 & 1/30/1995 & 7/3/1995 & Promus & Promus Hotel \\
\hline 56 & $4 / 24 / 1990$ & 7/16/1991 & Quaker Oats & Fisher-Price \\
\hline 14 & 8/16/1993 & 3/31/1994 & Ralston Purina & Ralcorp Holdings \\
\hline 28 & 6/29/1998 & 12/31/1998 & Rockwell International & Conexant Systems \\
\hline 28 & 3/17/1997 & 10/2/1997 & Rockwell International & Meritor Automotive \\
\hline 14 & 4/29/1999 & 11/4/1999 & Tenneco & Packaging Corp. of America \\
\hline 67 & 9/24/1996 & 12/10/1997 & Thermo Electron & Thermo Vision \\
\hline 28 & 12/16/1991 & 7/6/1992 & Union Carbide & Praxair \\
\hline 12 & 1/16/1998 & 6/10/1998 & US Office Products & Aztec Technology Partners ${ }^{2}$ \\
\hline 12 & $1 / 16 / 1998$ & 6/10/1998 & US Office Products & School Specialty ${ }^{2}$ \\
\hline 27 & 7/21/1999 & $3 / 23 / 2000$ & Weatherford International & Grant Prideco \\
\hline 15 & 6/23/1997 & 1/30/1998 & Whitman & Hussmann International $^{2}$ \\
\hline 6 & 9/18/1987 & 1/1/1989 & Whitman & Illinois Central Transportation \\
\hline 11 & 6/23/1997 & $1 / 30 / 1998$ & Whitman & Midas $^{2}$ \\
\hline 12 & 9/28/1990 & 4/2/1991 & Whitman & Pet \\
\hline 78 & $11 / 1 / 2000$ & $6 / 7 / 2001$ & WorldCom & MCI Group ${ }^{3}$ \\
\hline
\end{tabular}

${ }^{1}$ Bristol-Myers Squibb announced its planned divestiture of Zimmer on September 28, 2000. On February 22, 2001, it announced that the divestiture would be structured as a tax-free spin-off to shareholders.

${ }^{2}$ Part of a multiple divestiture

${ }^{3}$ Tracking stock issue 


\section{Table 2. Financial Characteristics of Spinoff Parent and Subsidiary Firms, 1985-2001}

The sample is a random sample of 62 refocusing transactions (spinoffs and tracking stock issues) announced between 1985 and 2000. All variables are measured at the end of the fiscal year in which each spinoff became effective.

\begin{tabular}{|c|c|c|c|c|c|c|}
\hline & & Means & & & Medians & \\
\hline & Parent & Subsidiary & t-stat. & $\underline{\text { Parent }}$ & Subsidiary & $\operatorname{Chi}^{2}(1)$ \\
\hline Sales $(\$ 000)$ & $9,281.6$ & $2,202.4$ & $2.40^{* *}$ & $3,692.0$ & $1,189.3$ & $6.34^{* * *}$ \\
\hline Assets (\$000) & $12,519.8$ & $1,989.4$ & $2.14^{* *}$ & $3,461.6$ & $1,036.1$ & $5.98^{* * *}$ \\
\hline Debt/Assets & 0.299 & 0.302 & -0.07 & 0.270 & 0.246 & 0.67 \\
\hline EBIT/Sales & 0.124 & 0.008 & 1.30 & 0.114 & 0.081 & $1.89^{*}$ \\
\hline CAPEX/Sales & 0.074 & 0.188 & -0.92 & 0.055 & 0.047 & 0.91 \\
\hline Market Value (\$000) & $11,765.5$ & $1,674.6$ & $3.44^{* * *}$ & $3,474.6$ & $1,049.3$ & $5.31^{* * *}$ \\
\hline Tobin’s q & 2.035 & 2.196 & -0.51 & 1.858 & 1.587 & 1.53 \\
\hline Number of Unique Companies & 52 & 62 & $\mathrm{n} / \mathrm{a}$ & 52 & 62 & $\mathrm{n} / \mathrm{a}$ \\
\hline
\end{tabular}




\section{Table 3. Information Content of Analyst Reports about Upcoming Spinoffs}

Percentage of reports that provide information about the parent or subsidiary in a spinoff, or about the transaction itself. The sample consists of 1,793 analyst reports covering the parent company and/or the subsidiary from a random sample of 62 refocusing transactions (58 spinoffs and 4 tracking stock issues) announced between 1985 and 2000.

\begin{tabular}{|c|c|c|}
\hline \multicolumn{3}{|l|}{ Panel A. Company-Specific Information } \\
\hline & $\begin{array}{l}\text { Parent-Only } \\
\text { Information }\end{array}$ & $\begin{array}{l}\text { Subsidiary-Only } \\
\text { Information }\end{array}$ \\
\hline \multicolumn{3}{|l|}{ Price Targets } \\
\hline Stock Price & $32.7 \%$ & $38.4 \%$ \\
\hline Market Value & $4.1 \%$ & $7.0 \%$ \\
\hline \multicolumn{3}{|l|}{ EPS Forecasts } \\
\hline Parent- or Subsidiary-Only EPS Forecasts & $26.3 \%$ & $19.5 \%$ \\
\hline Consolidated EPS Forecasts & $53.3 \%$ & $\mathrm{n} / \mathrm{a}$ \\
\hline Both Parent-Only EPS and Consolidated EPS Forecasts & $0.9 \%$ & $\mathrm{n} / \mathrm{a}$ \\
\hline No EPS Forecasts & $19.5 \%$ & $80.5 \%$ \\
\hline EPS Growth & $45.6 \%$ & $2.7 \%$ \\
\hline PE Forecasts & $77.2 \%$ & $7.8 \%$ \\
\hline \multicolumn{3}{|l|}{ Other Profit Forecasts * } \\
\hline CF or CF/Share & $9.1 \%$ & $0.8 \%$ \\
\hline Revenue & $2.1 \%$ & $0.8 \%$ \\
\hline EBITDA or EBITDA/Share & $4.0 \%$ & $3.2 \%$ \\
\hline EBIT or EBT & $1.5 \%$ & $1.3 \%$ \\
\hline Net Income & $3.0 \%$ & $0.6 \%$ \\
\hline ROE & $5.5 \%$ & $0.4 \%$ \\
\hline TEV/EBITDA & $1.8 \%$ & $0.3 \%$ \\
\hline Total Other Profit Forecasts & $33.0 \%$ & $8.8 \%$ \\
\hline \multicolumn{3}{|l|}{ Financial Statements Forecasts } \\
\hline Income Statement & $21.4 \%$ & $7.6 \%$ \\
\hline Balance Sheet & $6.4 \%$ & $2.3 \%$ \\
\hline Cash Flow Statement & $7.2 \%$ & $2.5 \%$ \\
\hline \multicolumn{3}{|l|}{ Valuation Methods ** } \\
\hline PE Multiple & $32.1 \%$ & $10.8 \%$ \\
\hline Other Multiple & $7.7 \%$ & $8.0 \%$ \\
\hline DCF & $1.4 \%$ & $1.2 \%$ \\
\hline Avge. Number of Pages Discussing Company or Industry & 3.3 & 0.9 \\
\hline Avge. Fraction of Total Pages in Report Discussing Company or Industry & 0.6 & 0.1 \\
\hline
\end{tabular}


Table 3. Information Content of Analyst Reports about Upcoming Spinoffs (continued)

Panel B. Spinoff-Specific Information

Percentage of Reports that Discuss or Provide Analysis of:

Parent or Subsidiary's Competitors $\quad 32.9 \%$

$\begin{array}{ll}\text { Rationale for Spinoff } & 26.4 \%\end{array}$

Transaction Costs of Spinoff $\quad 8.4 \%$

Conglomerate Discount $13.3 \%$

Allocation of Debt or Overhead $13.8 \%$

Business Segment Financial Information $\quad 35.4 \%$

Stock Recommendation

$\begin{array}{ll}\text { Buy/Positive } & 62.0 \%\end{array}$

$\begin{array}{ll}\text { Sell/Negative } & 0.8 \%\end{array}$

Hold/Neutral $\quad 24.7 \%$

$\begin{array}{ll}\text { None } & 12.5 \%\end{array}$

Opinion about Spinoff

Positive

$34.7 \%$

Negative

$1.0 \%$

$\begin{array}{ll}\text { Neutral/Mixed } & 48.7 \%\end{array}$

$\begin{array}{ll}\text { None } & 15.6 \%\end{array}$

$\begin{array}{ll}\text { Number of Reports } & 1,793\end{array}$

Average Number of Reports per Spinoff $\quad 28.9$

Average Number of Reports per Deal $\quad 8.5$ 


\section{Table 4. Earnings and Price Forecast Accuracy around Spinoffs}

Errors in analyst forecasts of earnings-per-share and stock price. Forecast errors are measured in several alternative ways, as indicated in the table. When EPS Forecast Error is measured as the absolute difference between forecasted EPS and actual EPS on the forecast date, scaled by the company's stock price, the parent's stock price is measured at the end of the fiscal year prior to the forecast period, while the subsidiary's stock price is measured at the end of the first fiscal year in which the stock trades. For Price Forecast Error, stock price is always measured as of the forecast date unless otherwise specified. The sample consists of 1,793 analyst reports covering the parent company and/or the subsidiary from a random sample of 62 refocusing transactions (58 spinoffs and 4 tracking stock issues) announced between 1985 and 2000.

\begin{tabular}{|c|c|c|c|c|}
\hline & \multicolumn{2}{|c|}{$\begin{array}{c}\text { Parent } \\
\text { Forecast Errors }\end{array}$} & \multicolumn{2}{|c|}{$\begin{array}{c}\text { Subsidiary } \\
\text { Forecast Errors }\end{array}$} \\
\hline & Mean & Median & Mean & Median \\
\hline \multicolumn{5}{|l|}{ Panel A. EPS Forecast Errors } \\
\hline 1. Absolute Error Relative to Actual Price: $\left|E_{F}-E_{A}\right| / P_{A}$ & $5.60 \%$ & $1.30 \%$ & $7.50 \%$ & $3.30 \%$ \\
\hline 2. Absolute Error Relative to Actual EPS: $\left|E_{F}-E_{A}\right| / E_{A}$ & $34.58 \%$ & $11.30 \%$ & $51.25 \%$ & $44.44 \%$ \\
\hline Number of Reports Containing EPS Forecasts & \multicolumn{2}{|c|}{1,400} & \multicolumn{2}{|c|}{263} \\
\hline \multicolumn{5}{|l|}{ Panel B. Price Forecast Errors } \\
\hline 1. Absolute Error Relative to Actual Price: $\left|P_{F}-P_{A}\right| / P_{A}$ & $44.10 \%$ & $21.10 \%$ & $47.90 \%$ & $26.40 \%$ \\
\hline 2. Log of Ratio of Target to Actual Price: $\operatorname{Ln}\left(P_{F} / P_{A}\right)$ & $42.86 \%$ & $23.50 \%$ & $42.17 \%$ & $31.60 \%$ \\
\hline \multicolumn{5}{|l|}{ 3. a) If Target Price $P_{F}>$ Actual Price $P_{A}$ on Report Date: } \\
\hline$\%$ of Reports where $P_{A} \geq P_{F}$ within 12 Months & $65.93 \%$ & $\mathrm{n} / \mathrm{a}$ & $46.08 \%$ & $\mathrm{n} / \mathrm{a}$ \\
\hline 12-Month Maximum $P_{A}$ Relative to Target Price $P_{F}$ & $146.68 \%$ & $128.16 \%$ & $127.72 \%$ & $116.58 \%$ \\
\hline \multicolumn{5}{|l|}{ b) If Target Price $P_{F}<$ Actual Price $P_{A}$ on Report Date: } \\
\hline$\%$ of Reports where $P_{A} \leq P_{F}$ within 12 Months & $34.07 \%$ & $\mathrm{n} / \mathrm{a}$ & $53.92 \%$ & $\mathrm{n} / \mathrm{a}$ \\
\hline 12-Month Minimum $P_{A}$ Relative to Target Price $P_{F}$ & $120.29 \%$ & $112.16 \%$ & $126.87 \%$ & $119.05 \%$ \\
\hline Number of Reports Containing Price Forecasts & \multicolumn{2}{|c|}{587} & \multicolumn{2}{|c|}{683} \\
\hline
\end{tabular}




\section{Table 5. Summary Statistics}

Summary statistics for key variables. The sample consists of 1,793 analyst reports covering the parent company and/or the subsidiary from a random sample of 62 refocusing transactions (58 spinoffs and 4 tracking stock issues) announced between 1985 and 2000.

\begin{tabular}{|c|c|c|c|c|}
\hline & \multicolumn{2}{|c|}{$\begin{array}{c}\text { Parent-Level } \\
\text { Variables }\end{array}$} & \multicolumn{2}{|c|}{$\begin{array}{c}\text { Subsidiary-Level } \\
\text { Variables }\end{array}$} \\
\hline & Mean & S.D. & Mean & S.D. \\
\hline Parent or Subsidiary Share of Report Pages & 0.607 & 0.384 & 0.149 & 0.246 \\
\hline Total Report Pages & 5.666 & 7.375 & 5.666 & 7.375 \\
\hline Number of Annual Parent or Subsidiary EPS Forecasts & 1.632 & 0.907 & 0.345 & 0.772 \\
\hline Parent or Subsidiary Price Forecast & 0.327 & 0.469 & 0.384 & 0.486 \\
\hline Parent or Subsidiary EPS Growth Forecast & 0.456 & 0.498 & 0.027 & 0.161 \\
\hline Parent or Subsidiary PE Forecast & 0.772 & 0.419 & 0.078 & 0.268 \\
\hline Parent or Subsidiary Other Forecast & 0.330 & 0.470 & 0.088 & 0.283 \\
\hline Parent or Subsidiary Financial Statement Index & 0.349 & 0.729 & 0.124 & 0.449 \\
\hline Spinoff Analysis Index & 1.247 & 1.313 & 1.247 & 1.313 \\
\hline Days from Announcement to Report Date & 117.853 & 102.133 & 117.853 & 102.133 \\
\hline Ln(Total Assets of Parent or Subsidiary) & 9.283 & 1.315 & 7.375 & 1.613 \\
\hline Total Assets of Subsidiary / Total Assets of Parent & 0.455 & 1.185 & 0.455 & 1.185 \\
\hline Relatedness & 0.090 & 0.287 & 0.090 & 0.287 \\
\hline Analyst Ranking by II & 0.934 & 1.428 & 0.934 & 1.428 \\
\hline Broker Reputation Ranking & 3.689 & 6.941 & 3.689 & 6.941 \\
\hline Analyst Provides $10 \%+$ of Broker's Reports in Sector & 0.807 & 0.395 & 0.807 & 0.395 \\
\hline Broker Provides $2 \%+$ of Reports in Sector & 0.489 & 0.500 & 0.489 & 0.500 \\
\hline Analyst Advisor & 0.173 & 0.733 & 0.173 & 0.733 \\
\hline Optimistic Spinoff Spin & 0.347 & 0.476 & 0.347 & 0.476 \\
\hline Pessimistic Spinoff Spin & 0.010 & 0.100 & 0.010 & 0.100 \\
\hline
\end{tabular}




\section{Table 6. Information Content of Analyst Reports and Earnings Forecast Accuracy: Ordinary Least Squares}

Ordinary Least Squares regressions of earnings-per-share (EPS) forecast errors on various items of information contained in analyst reports. EPS Forecast Error is measured as the absolute difference between forecasted EPS and actual EPS on the forecast date, scaled by the company's stock price: $\left|E_{F}-E_{A}\right| / P_{A}$. For the parent forecast error, stock price is measured at the end of the fiscal year prior to the forecast period. For the subsidiary forecast error, stock price is measured at the end of the first fiscal year in which the stock trades. The sample consists of 1,793 analyst reports covering the parent company and/or the subsidiary from a random sample of 62 refocusing transactions (58 spinoffs and 4 tracking stock issues) announced between 1985 and 2000. Robust standard errors clustered at the analyst-level are in parentheses. Asterisks denote statistical significance at the $1 \%\left({ }^{* * *}\right), 5 \%\left({ }^{* *}\right)$, or $10 \%(*)$ level, respectively.

\begin{tabular}{|c|c|c|c|c|}
\hline & \multicolumn{2}{|c|}{$\begin{array}{c}\text { Parent EPS } \\
\text { Forecast Errors [1] }\end{array}$} & \multicolumn{2}{|c|}{$\begin{array}{c}\text { Subsidiary EPS } \\
\text { Forecast Errors [2] }\end{array}$} \\
\hline & Coef. & S.E. & Coef. & S.E. \\
\hline Parent or Subsidiary Share of Report Pages & $-0.060 * *$ & 0.023 & 0.032 & 0.024 \\
\hline Total Report Pages & 0.001 & 0.001 & 0.000 & 0.001 \\
\hline Parent or Subsidiary Price Forecast & 0.004 & 0.008 & $-0.037 * *$ & 0.017 \\
\hline Number of Annual Parent or Subsidiary EPS Forecasts & $-0.032 * * *$ & 0.010 & 0.010 & 0.011 \\
\hline Parent or Subsidiary EPS Growth Forecast & -0.021 & 0.014 & 0.034 & 0.042 \\
\hline Parent or Subsidiary PE Forecast & 0.012 & 0.015 & 0.007 & 0.020 \\
\hline Parent or Subsidiary Other Forecast & $-0.024 * *$ & 0.011 & -0.014 & 0.020 \\
\hline Parent or Subsidiary Financial Statement Index & $0.019 * * *$ & 0.007 & 0.017 & 0.012 \\
\hline Spinoff Analysis Index & -0.007 & 0.004 & 0.003 & 0.006 \\
\hline Days from Announcement to Report Date & $-0.000 *$ & 0.000 & $-0.000 *$ & 0.000 \\
\hline Ln(Total Assets of Parent or Subsidiary) & $0.011 * * *$ & 0.004 & $0.024 *$ & 0.014 \\
\hline Total Assets of Subsidiary / Total Assets of Parent & $0.037 * * *$ & 0.006 & 0.000 & 0.020 \\
\hline Relatedness & $-0.068 * * *$ & 0.023 & -0.101 & 0.064 \\
\hline Analyst Ranking by II & $0.011^{*}$ & 0.006 & 0.001 & 0.007 \\
\hline Broker Reputation Ranking & $0.002 *$ & 0.001 & -0.001 & 0.002 \\
\hline Analyst Provides $10 \%+$ of Broker's Reports in Sector & $-0.022 *$ & 0.011 & -0.015 & 0.032 \\
\hline Broker Provides $2 \%+$ of Reports in Sector & $-0.043^{* * *}$ & 0.014 & $0.037 *$ & 0.021 \\
\hline Analyst Advisor & $-0.016 *$ & 0.008 & $-0.024 * *$ & 0.011 \\
\hline Optimistic Spinoff Spin & $-0.023^{*}$ & 0.012 & -0.019 & 0.012 \\
\hline Pessimistic Spinoff Spin & 0.087 & 0.074 & 0.137 & 0.124 \\
\hline Constant & 0.038 & 0.040 & -0.057 & 0.102 \\
\hline Observations & \multicolumn{2}{|c|}{1,400} & \multicolumn{2}{|c|}{263} \\
\hline R-squared & \multicolumn{2}{|c|}{0.220} & \multicolumn{2}{|c|}{0.551} \\
\hline
\end{tabular}




\section{Table 7. Information Content of Analyst Reports and Earnings Forecast Accuracy: Analyst Fixed Effects}

Analyst fixed effects regressions of earnings-per-share (EPS) forecast errors on various items of information contained in analyst reports. EPS Forecast Error is measured as the absolute difference between forecasted EPS and actual EPS on the forecast date, scaled by the company's stock price: $\left|E_{F}-E_{A}\right| / P_{A}$. For the parent forecast error, stock price is measured at the end of the fiscal year prior to the forecast period. For the subsidiary forecast error, stock price is measured at the end of the first fiscal year in which the stock trades. The sample consists of 1,793 analyst reports covering the parent company and/or the subsidiary from a random sample of 62 refocusing transactions (58 spinoffs and 4 tracking stock issues) announced between 1985 and 2000. Robust standard errors clustered at the analyst-level are in parentheses. Asterisks denote statistical significance at the $1 \%(* * *), 5 \%(* *)$, or $10 \%(*)$ level, respectively.

\begin{tabular}{|c|c|c|c|c|}
\hline & \multicolumn{2}{|c|}{$\begin{array}{c}\text { Parent EPS } \\
\text { Forecast Errors [1] }\end{array}$} & \multicolumn{2}{|c|}{$\begin{array}{c}\text { Subsidiary EPS } \\
\text { Forecast Errors [2] }\end{array}$} \\
\hline & Coef. & S.E. & Coef. & S.E. \\
\hline Parent or Subsidiary Share of Report Pages & $-0.018^{*}$ & 0.010 & 0.014 & 0.018 \\
\hline Total Report Pages & 0.000 & 0.000 & -0.001 & 0.001 \\
\hline Parent or Subsidiary Price Forecast & 0.000 & 0.005 & 0.046 & 0.029 \\
\hline Number of Annual Parent or Subsidiary EPS Forecasts & $-0.020 * *$ & 0.008 & -0.011 & 0.009 \\
\hline Parent or Subsidiary EPS Growth Forecast & 0.001 & 0.012 & 0.054 & 0.035 \\
\hline Parent or Subsidiary PE Forecast & 0.015 & 0.011 & -0.008 & 0.020 \\
\hline Parent or Subsidiary Other Forecast & 0.006 & 0.007 & 0.030 & 0.021 \\
\hline Parent or Subsidiary Financial Statement Index & 0.000 & 0.006 & 0.016 & 0.014 \\
\hline Spinoff Analysis Index & 0.001 & 0.003 & -0.014 & 0.012 \\
\hline Days from Announcement to Report Date & $0.000 * *$ & 0.000 & 0.000 & 0.000 \\
\hline Ln(Total Assets of Parent or Subsidiary) & $-0.044 *$ & 0.024 & 0.041 & 0.059 \\
\hline Total Assets of Subsidiary / Total Assets of Parent & $0.032 * *$ & 0.016 & -0.022 & 0.184 \\
\hline Relatedness & $-0.126^{* *}$ & 0.061 & 0.000 & 0.000 \\
\hline Analyst Ranking by II & -0.016 & 0.013 & -0.012 & 0.029 \\
\hline Broker Reputation Ranking & -0.001 & 0.002 & 0.000 & 0.003 \\
\hline Analyst Provides $10 \%+$ of Broker's Reports in Sector & -0.034 & 0.029 & -0.041 & 0.066 \\
\hline Broker Provides 2\%+ of Reports in Sector & -0.055 & 0.041 & -0.009 & 0.115 \\
\hline Analyst Advisor & $-0.105^{*}$ & 0.058 & 0.084 & 0.116 \\
\hline Optimistic Spinoff Spin & -0.003 & 0.006 & 0.012 & 0.016 \\
\hline Pessimistic Spinoff Spin & -0.030 & 0.021 & -0.038 & 0.028 \\
\hline Constant & $0.510^{* *}$ & 0.236 & -0.185 & 0.324 \\
\hline Observations & 1,4 & & 2 & \\
\hline R-squared & 0.3 & & & \\
\hline
\end{tabular}




\section{Table 8. Information Content of Analyst Reports and Earnings Forecast Accuracy: Heckman Two-Stage Models}

Heckman two-stage regressions of earnings-per-share (EPS) forecast errors on various items of information contained in analyst reports. The dependent variable in the first stage is the probability that the analyst report contains EPS Forecasts for the parent or subsidiary company (depending on the regression). The dependent variable in the second stage is EPS Forecast Error, measured as the absolute difference between forecasted EPS and actual EPS on the forecast date, scaled by the company's stock price: $\left|E_{F}-E_{A}\right| / P_{A}$. For the parent forecast error, stock price is measured at the end of the fiscal year prior to the forecast period. For the subsidiary forecast error, stock price is measured at the end of the first fiscal year in which the stock trades. The sample consists of 1,793 analyst reports covering the parent company and/or the subsidiary from a random sample of 62 refocusing transactions (58 spinoffs and 4 tracking stock issues) announced between 1985 and 2000. Robust standard errors are in parentheses. Asterisks denote statistical significance at the $1 \%(* * *), 5 \%(* *)$, or $10 \%(*)$ level, respectively.

\begin{tabular}{|c|c|c|c|c|}
\hline & \multicolumn{2}{|c|}{$\begin{array}{c}\text { Parent EPS } \\
\text { Forecast Error [1] }\end{array}$} & \multicolumn{2}{|c|}{$\begin{array}{c}\text { Subsidiary EPS } \\
\text { Forecast Error [2] }\end{array}$} \\
\hline & Stage 1 & Stage 2 & Stage 1 & Stage 2 \\
\hline & $\operatorname{Pr}[$ Forecast $]$ & Error & $\operatorname{Pr}[$ Forecast $]$ & Error \\
\hline \multirow[t]{2}{*}{ Subsidiary IPO / Parent IPO } & $-0.034 * * *$ & & $0.030 * * *$ & \\
\hline & 0.010 & & 0.011 & \\
\hline \multirow[t]{2}{*}{ Parent or Subsidiary Share of Report Pages } & $0.606 * * *$ & $-0.059 * * *$ & 0.159 & 0.034 \\
\hline & 0.190 & 0.013 & 0.249 & 0.024 \\
\hline \multirow[t]{2}{*}{ Total Report Pages } & -0.006 & 0.001 & 0.001 & 0.000 \\
\hline & 0.008 & 0.001 & 0.007 & 0.001 \\
\hline \multirow[t]{2}{*}{ Parent or Subsidiary Price Forecast } & $0.426 * * *$ & 0.005 & $0.632 * * *$ & -0.020 \\
\hline & 0.144 & 0.009 & 0.139 & 0.022 \\
\hline \multirow[t]{2}{*}{ No. of Annual Parent or Subsidiary EPS Forecasts } & $1.390 * * *$ & $-0.029 * * *$ & $1.268 * * *$ & $0.029 *$ \\
\hline & 0.100 & 0.009 & 0.085 & 0.017 \\
\hline \multirow[t]{2}{*}{ Parent or Subsidiary EPS Growth Forecast } & -0.081 & $-0.021 * *$ & -0.044 & 0.034 \\
\hline & 0.147 & 0.008 & 0.281 & 0.024 \\
\hline \multirow[t]{2}{*}{ Parent or Subsidiary PE Forecast } & $1.230 * * *$ & 0.017 & $0.336 *$ & 0.013 \\
\hline & 0.164 & 0.017 & 0.181 & 0.018 \\
\hline \multirow[t]{2}{*}{ Parent or Subsidiary Other Forecast } & 0.025 & $-0.025 * * *$ & 0.282 & -0.011 \\
\hline & 0.145 & 0.009 & 0.180 & 0.017 \\
\hline \multirow[t]{2}{*}{ Parent or Subsidiary Financial Statement Index } & -0.134 & $0.019 * * *$ & -0.039 & $0.017^{*}$ \\
\hline & 0.092 & 0.006 & 0.113 & 0.010 \\
\hline \multirow[t]{2}{*}{ Spinoff Analysis Index } & 0.037 & $-0.006 *$ & $0.095 *$ & 0.004 \\
\hline & 0.058 & 0.004 & 0.054 & 0.006 \\
\hline \multirow[t]{2}{*}{ Days from Announcement to Report Date } & 0.001 & $-0.000 *$ & 0.000 & $-0.000 *$ \\
\hline & 0.001 & 0.000 & 0.001 & 0.000 \\
\hline \multirow[t]{2}{*}{ Ln(Total Assets of Parent or Subsidiary) } & -0.070 & $0.012 * * *$ & 0.002 & $0.021 * * *$ \\
\hline & 0.055 & 0.004 & 0.055 & 0.007 \\
\hline \multirow[t]{2}{*}{ Total Assets of Subsidiary / Total Assets of Parent } & $-0.380 * * *$ & $0.036 * * *$ & 0.091 & 0.007 \\
\hline & 0.065 & 0.005 & 0.091 & 0.013 \\
\hline \multirow[t]{2}{*}{ Relatedness } & -0.409 & $-0.068 * * *$ & 0.107 & $-0.103 * * *$ \\
\hline & 0.273 & 0.019 & 0.317 & 0.037 \\
\hline \multirow[t]{2}{*}{ Analyst Ranking by II } & 0.031 & $0.011 * * *$ & -0.035 & 0.001 \\
\hline & 0.041 & 0.003 & 0.045 & 0.005 \\
\hline Broker Reputation Ranking & $0.041^{* * *}$ & $0.002 * * *$ & $0.028 * * *$ & -0.001 \\
\hline
\end{tabular}




\begin{tabular}{lcccc} 
& 0.008 & 0.001 & 0.010 & 0.001 \\
Analyst Provides 10\%+ of Broker's Reports in Sector & $0.280^{*}$ & $-0.021^{*}$ & $-0.330^{*}$ & -0.023 \\
& 0.169 & 0.011 & 0.170 & 0.021 \\
Broker Provides 2\%+ of Reports in Sector & -0.046 & $-0.044^{* * *}$ & -0.110 & $0.033^{*}$ \\
& 0.142 & 0.009 & 0.142 & 0.018 \\
Analyst Advisor & 0.058 & $-0.015^{* *}$ & 0.031 & $-0.024^{* *}$ \\
Optimistic Spinoff Spin & 0.083 & 0.006 & 0.108 & 0.012 \\
& 0.046 & $-0.023^{* *}$ & -0.170 & -0.020 \\
Pessimistic Spinoff Spin & 0.139 & 0.009 & 0.142 & 0.015 \\
& 5.306 & $0.089^{* *}$ & 0.171 & $0.142^{* *}$ \\
Constant & 0.000 & 0.035 & 0.570 & 0.064 \\
& -1.333 & 0.023 & $-2.302^{* * *}$ & -0.117 \\
Lambda & 0.952 & 0.050 & 0.534 & 0.083 \\
Observations & & 0.019 & & 0.044 \\
\hline
\end{tabular}




\section{Table 9. Impact of Subsidiary Forecast Accuracy on Parent Forecast Accuracy}

Heckman two-stage regressions of earnings-per-share (EPS) forecast errors on various items of information contained in analyst reports. The dependent variable in the first stage is the probability that the analyst report contains EPS Forecasts for the subsidiary company. The dependent variable in the second stage is Parent EPS Forecast Error, measured as the absolute difference between forecasted EPS and actual EPS on the forecast date, scaled by the company's stock price: $\left|E_{F}-E_{A}\right| / P_{A}$. Stock price is measured at the end of the fiscal year prior to the forecast period. The sample consists of 1,793 analyst reports covering the parent company and/or the subsidiary from a random sample of 62 refocusing transactions (58 spinoffs and 4 tracking stock issues) announced between 1985 and 2000. Robust standard errors are in parentheses. Asterisks denote statistical significance at the $1 \%\left({ }^{* * *}\right)$, $5 \%(* *)$, or $10 \%\left(^{*}\right)$ level, respectively.

\begin{tabular}{|c|c|c|}
\hline & \multicolumn{2}{|c|}{ Parent EPS Forecast Error } \\
\hline & Stage 1 & Stage 2 \\
\hline & $\operatorname{Pr}[$ Subsidiary Forecast $]$ & Parent Forecast Error \\
\hline \multirow[t]{2}{*}{ Subsidiary IPO / Parent IPO } & $0.029 * *$ & \\
\hline & 0.013 & \\
\hline \multirow[t]{2}{*}{ Subsidiary EPS Forecast Error } & & $0.156 * *$ \\
\hline & & 0.070 \\
\hline \multirow[t]{2}{*}{ Parent or Subsidiary Share of Report Pages } & -0.417 & $-0.093 * * *$ \\
\hline & 0.276 & 0.033 \\
\hline \multirow[t]{2}{*}{ Total Report Pages } & 0.009 & -0.001 \\
\hline & 0.007 & 0.001 \\
\hline \multirow[t]{2}{*}{ Parent or Subsidiary Price Forecast } & $0.750 * * *$ & 0.003 \\
\hline & 0.151 & 0.020 \\
\hline \multirow[t]{2}{*}{ No. of Annual Parent or Subsidiary EPS Forecasts } & $1.293 * * *$ & -0.004 \\
\hline & 0.091 & 0.012 \\
\hline \multirow[t]{2}{*}{ Parent or Subsidiary EPS Growth Forecast } & -0.189 & -0.006 \\
\hline & 0.346 & 0.017 \\
\hline \multirow[t]{2}{*}{ Parent or Subsidiary PE Forecast } & 0.066 & 0.011 \\
\hline & 0.205 & 0.028 \\
\hline \multirow[t]{2}{*}{ Parent or Subsidiary Other Forecast } & $0.371^{*}$ & -0.003 \\
\hline & 0.200 & 0.018 \\
\hline \multirow[t]{2}{*}{ Parent or Subsidiary Financial Statement Index } & $-0.220^{*}$ & $0.017^{*}$ \\
\hline & 0.134 & 0.010 \\
\hline \multirow[t]{2}{*}{ Spinoff Analysis Index } & $0.141^{* *}$ & -0.010 \\
\hline & 0.058 & 0.008 \\
\hline \multirow[t]{2}{*}{ Days from Announcement to Report Date } & -0.001 & $-0.000 *$ \\
\hline & 0.001 & 0.000 \\
\hline \multirow[t]{2}{*}{ Ln(Total Assets of Parent or Subsidiary) } & 0.042 & -0.012 \\
\hline & 0.068 & 0.010 \\
\hline \multirow[t]{2}{*}{ Total Assets of Subsidiary / Total Assets of Parent } & 0.015 & $0.047 * * *$ \\
\hline & 0.105 & 0.014 \\
\hline \multirow[t]{2}{*}{ Relatedness } & 0.318 & $-0.127 * * *$ \\
\hline & 0.341 & 0.047 \\
\hline \multirow[t]{2}{*}{ Analyst Ranking by II } & -0.024 & 0.006 \\
\hline & 0.048 & 0.006 \\
\hline \multirow[t]{2}{*}{ Broker Reputation Ranking } & $0.028 * * *$ & $0.001 * * *$ \\
\hline & 0.011 & 0.001 \\
\hline
\end{tabular}




\begin{tabular}{lcc} 
Analyst Provides 10\%+ of Broker's Reports in Sector & $-0.394^{* *}$ & 0.003 \\
Broker Provides 2\%+ of Reports in Sector & 0.177 & 0.024 \\
& -0.061 & -0.065 \\
Analyst Advisor & 0.152 & 0.021 \\
& 0.032 & 0.011 \\
Optimistic Spinoff Spin & 0.121 & 0.018 \\
& $-0.280^{*}$ & $-0.038^{* *}$ \\
Pessimistic Spinoff Spin & 0.156 & 0.019 \\
& 0.422 & -0.045 \\
Constant & 0.549 & 0.063 \\
Lambda & $-2.623^{* * *}$ & 0.164 \\
Observations & 0.613 & 0.113 \\
\hline
\end{tabular}




\section{Table 10. Information Content of Analyst Reports and Price Forecast Accuracy}

Ordinary Least Squares regressions of price forecast errors on various items of information contained in analyst reports. Price Forecast Error is measured as the absolute difference between forecasted (target) stock price and actual stock price on the forecast date, scaled by the company's stock price on the same date: $\left|P_{F}-P_{A}\right| / P_{A}$. The sample consists of 1,793 analyst reports covering the parent company and/or the subsidiary from a random sample of 62 refocusing transactions (58 spinoffs and 4 tracking stock issues) announced between 1985 and 2000. Robust standard errors are in parentheses. Asterisks denote statistical significance at the $1 \%(* * *), 5 \%(* *)$, or $10 \%(*)$ level, respectively.

\begin{tabular}{|c|c|c|c|c|}
\hline & \multicolumn{2}{|c|}{$\begin{array}{c}\text { Parent Price Forecast } \\
\text { Errors [1] }\end{array}$} & \multicolumn{2}{|c|}{$\begin{array}{c}\text { Subsidiary Price } \\
\text { Forecast Errors [2] }\end{array}$} \\
\hline & Coef. & S.E. & Coef. & S.E. \\
\hline Parent or Subsidiary Share of Report Pages & 0.061 & 0.104 & 0.079 & 0.112 \\
\hline Total Report Pages & 0.000 & 0.007 & 0.000 & 0.003 \\
\hline Number of Annual Parent or Subsidiary EPS Forecasts & 0.008 & 0.051 & 0.012 & 0.047 \\
\hline Parent or Subsidiary EPS Growth Forecast & $-0.112 * *$ & 0.051 & -0.050 & 0.101 \\
\hline Parent or Subsidiary PE Forecast & -0.291 & 0.180 & -0.054 & 0.089 \\
\hline Parent or Subsidiary Other Forecast & 0.067 & 0.069 & $-0.479 * * *$ & 0.132 \\
\hline Parent or Subsidiary Financial Statement Index & -0.087 & 0.084 & $0.111^{*}$ & 0.066 \\
\hline Spinoff Analysis Index & $0.055^{* *}$ & 0.028 & -0.036 & 0.031 \\
\hline Days from Announcement to Report Date & 0.000 & 0.000 & $-0.001 * *$ & 0.000 \\
\hline Ln(Total Assets of Parent or Subsidiary) & $-0.109 * *$ & 0.044 & 0.023 & 0.025 \\
\hline Total Assets of Subsidiary / Total Assets of Parent & -0.033 & 0.069 & 0.049 & 0.055 \\
\hline Relatedness & 0.089 & 0.392 & -0.118 & 0.132 \\
\hline Analyst Ranking by II & $-0.051 * *$ & 0.023 & 0.019 & 0.025 \\
\hline Broker Reputation Ranking & 0.005 & 0.004 & 0.007 & 0.005 \\
\hline Analyst Provides $10 \%+$ of Broker's Reports in Sector & 0.125 & 0.085 & 0.009 & 0.099 \\
\hline Broker Provides $2 \%+$ of Reports in Sector & -0.095 & 0.076 & -0.007 & 0.073 \\
\hline Analyst Advisor & -0.050 & 0.046 & -0.059 & 0.057 \\
\hline Optimistic Spinoff Spin & 0.001 & 0.072 & -0.024 & 0.070 \\
\hline Pessimistic Spinoff Spin & -0.282 & 0.182 & 0.557 & 0.677 \\
\hline Constant & $1.220 * * *$ & 0.350 & 0.296 & 0.200 \\
\hline Observations & 587 & & 683 & \\
\hline R-squared & 0.20 & & 0.333 & \\
\hline
\end{tabular}

